\title{
The unintended benefit of the risk factor mandate of 2005
}

\author{
Allen H. Huang ${ }^{1}$ (D) . Jianghua Shen ${ }^{2} \cdot$ Amy Y. Zang $^{1}$ \\ Accepted: 4 March 2021 / Published online: 14 April 2021 \\ (C) The Author(s) 2021, corrected publication 2021
}

\begin{abstract}
In 2005, the SEC mandated that firms disclose risk factors to provide useful information about firm risk. An unintended effect of the mandate is that mandatory risk factor (RF) disclosure may constitute "meaningful cautionary language" as defined in the Private Securities Litigation Reform Act, and may therefore provide legal protection for forward-looking statements (FLSs). Using both a difference-in-differences design and a two-stage least squares approach, we find that, following the mandate, firms that had not previously disclosed risk factors (late RF disclosers) became more willing to provide qualitative FLSs, particularly positive ones, than other firms. This finding is consistent with our prediction that, for late RF disclosers, the mandate reduces managers' perceived litigation risk. We also find that these firms experience improvement in their information environment. A path analysis reveals that the mandate improves firms' information environment not only directly but also indirectly by prompting more disclosure of positive FLSs, illustrating an unintended benefit of the $2005 \mathrm{RF}$ mandate. Cross-sectional tests show that the RF mandate induces a larger increase in positive FLSs for firms whose managers perceive a higher level of benefit from safe harbor protection arising from meaningful cautionary statements.
\end{abstract}

Keywords Risk factor disclosure - Litigation risk · Forward-looking statements · Voluntary disclosure $\cdot$ Information environment

JEL classification $\mathrm{K} 22 \cdot \mathrm{M} 41 \cdot \mathrm{M} 43$

Allen H. Huang

allen.huang@ust.hk

Jianghua Shen

jshen2018@xmu.edu.cn

Amy Y. Zang

amy.zang@ust.hk

1 Hong Kong University of Science and Technology, Hong Kong, China

2 Xiamen University, Xiamen, China 
"Are our rules the sole or primary cause of potential disclosure overload or do other sources contribute to it?"-Mary Jo White, Chair of the SEC, 2013

"Risk factor disclosures are a way of telling investors, 'Seriously, anything can happen ... ."'-A US Corporate Counsel, 2006

\section{Introduction}

In 2005, the Securities and Exchange Commission (SEC) promulgated a risk factor (RF) regulation (Securities Offering Reform, Item 503(c) of Regulation S-K) mandating that all firms disclose "the most significant factors that make the company speculative or risky" in Item 1A of their 10-K filings. This regulation was intended to induce firms to provide the market with more information and greater transparency about their risk (SEC 2013, 2016). However, the reality is that firms, driven by litigation concerns (Nelson and Pritchard 2016), fill their RF section with lengthy boilerplate discussions (Beatty et al. 2015; Dyer et al. 2017), which causes both market participants and regulators to complain about "disclosure overload" (Johnson 2010). ${ }^{1,2}$ SEC Chairwoman Mary Jo White makes the following observation:

Over time, this cautionary language [risk factor disclosure] became more and more extensive, not necessarily because of a change in the SEC requirements for risk factor disclosure (although it is now required in the 10-K) but, at least in part, because of legal advice from attorneys assisting with the preparation of filings. It may be difficult or unwise to significantly walk those disclosures back, but it is fair to ask whether there is more there than is really needed.

(White 2013)

In an effort to simplify and reduce the amount of mandatory disclosure, regulators asked for input from market participants and sought a comprehensive analysis of the costs and benefits of the RF disclosure mandate (White 2013; SEC 2016). Researchers responded by investigating whether mandated RF disclosure achieves the intended goal of providing useful information about a firm's risks. Several studies found evidence that the amount of disclosed risk factors is related to firms' fundamental risk and market-based risk, and concluded that RF disclosure indeed serves the intended regulatory purpose (Kravet and Muslu 2013; Campbell et al. 2014).

We extend the literature by focusing on the consequences of the 2005 RF mandate from the perspective of its legal implications. Court decisions and anecdotal evidence indicate that managers use RF disclosure as "meaningful cautionary language," as defined in the Private Securities Litigation Reform Act (PSLRA) of 1995,

\footnotetext{
${ }^{1}$ Beatty et al. (2015) show that the average length of Item 1A increased from $8.9 \%$ of a firm's $10-\mathrm{K}$ filing in 2006 to $16.5 \%$ in 2013. Dyer et al. (2017) conclude that RF disclosures are one of the three topics that account for virtually all of the increase in the $10-\mathrm{K}$ disclosure length.

${ }^{2}$ By boilerplate, we mean generic, standardized text that can be copied and used in documents with very small changes. This definition is consistent with that used by the SEC. In its guidelines on how to write clear disclosure documents, the SEC remarks that "so many of these sentences have become 'boilerplate' that writers cut and paste them into new documents without thinking" (SEC 1998).
} 
to provide safe harbor protection for forward-looking statements (FLSs; 15 USC $\S \S$ 77z-2(c)(1)(A)(i)). ${ }^{3}$ That is, although the SEC did not explicitly intend the 2005 RF mandate to provide safe harbor protection for FLSs, ${ }^{4}$ firms see RF disclosures as an "insurance" against litigation toward overly optimistic statements (White 2013; Shearman and Sterling 2014). ${ }^{5}$ We hypothesize that managers perceive an increase in safe harbor protection due to the $2005 \mathrm{RF}$ mandate, which prompts them to provide more FLSs, particularly positive ones. We further hypothesize that these additional FLSs have a positive effect on firms' information environment, which is an unintended benefit of the mandate.

Understanding the RF mandate's effect on firms' voluntary disclosure of qualitative FLSs is important for two reasons. ${ }^{6}$ First, despite the SEC's encouragement (SEC 1989, 2003, 2020), both investors and regulators find firms' forward-looking disclosures inadequate (SEC 1997b; Cole and Jones 2005; Garmong 2007; CFA Institute 2013, 2014; Muslu et al. 2015). The reluctance of managers to discuss projections and future plans is partly driven by their fear of securities class action lawsuits. In such lawsuits, shareholders often attribute their losses to managers' overly optimistic disclosures. Even with the PSLRA's safe harbor protection, plaintiff lawyers' targeting of qualitative FLSs is a norm in today's litigation environment. According to Cornerstone's annual review of securities class action filings, 57\% of the lawsuit filings from 2004 to 2018 involved allegations concerning misleading qualitative FLSs (Cornerstone Research 2008-2018). Empirical researchers find that plaintiff lawyers tend to target positive qualitative disclosures (Rogers et al. 2011), and that judges are less likely to dismiss lawsuits when the defendant firm has a larger amount of qualitative disclosure (Cutler et al. 2019). The apparent ineffectiveness of the PSLRA in stemming such lawsuits can be attributed to divergent, murky judicial interpretations of when and how safe harbor protection applies (Pritchard and Sale 2005; Horwich 2010; Olazabal 2011). Therefore, managers might be reluctant to provide FLSs when they perceive uncertainty about legal protection. We fill a

\footnotetext{
${ }^{3}$ Numerous district and circuit court decisions in class action lawsuits uphold that RF disclosures sufficiently meet the requirements for meaningful cautionary language. Section 2 provides a more detailed discussion of this.

${ }^{4}$ First, the SEC states clearly that "the risk factor section is intended to provide investors with a clear and concise summary of the material risks to an investment in the issuer's securities" (SEC 2005; 70 FR 44722, August 3, 2005). Second, in its cost-benefit analysis of the proposed RF disclosure mandate, the SEC does not include safe harbor protection as a benefit (see the "Cost Benefit Analysis" section of SEC 2005). Third, in reviewing all 137 comment letters that the SEC received for the proposed rule of Securities Offering Reform (available at https://www.sec.gov/rules/proposed/s73804.shtml), we find that although most commenters support the RF mandate, none of them suggest that increased forward-looking voluntary disclosure is a benefit. Thus, we conclude that providing safe harbor protection for FLSs is not a stated intention of the SEC's RF mandate.

5 Advising firms on how to write effective RF disclosures, two attorneys comment, "Risk factors can help protect the company from losing a shareholder lawsuit by helping to refute the claim that the company did not warn the shareholder of the possibility that something bad could occur. Hindsight being 20/20, companies that cannot point to such a factor when faced with a lawsuit will wish they could turn back the clock and insert such language. Risk factors therefore are often referred to as the "cheapest form of insurance"" (Robbins and Rothenberg 2005).

${ }^{6}$ We focus on qualitative forward-looking disclosures because they represent the majority of firm disclosures (Li 2010).
} 
gap in the literature by providing new insight showing that the RF mandate increases managers' perceived safe harbor protection, which prompts them to provide a larger amount of FLSs and more positive qualitative FLSs.

Second, as Leuz and Wysocki (2016) point out, understanding the consequences of disclosure regulation is of "first-order importance." They note that "the case in favor or against disclosure and reporting regulation is not ex ante obvious and that the relative magnitudes of various costs and benefits that arise from a mandate are largely an empirical matter." We reveal that the RF mandate unintentionally triggers a type of voluntary disclosure that is useful to investors and, in doing so, paint a more complete picture of the consequences or desirability of the RF mandate. Regulators should take our findings into account when evaluating the total effect of disclosure regulations.

To study the RF mandate's effect on firms' voluntary disclosure of FLSs, we first use a difference-in-differences (DiD) design to control for general trends in FLSs and gradual changes in other unobservable factors that might affect disclosure. Following studies on the consequences of International Financial Reporting Standards (IFRS) adoption (e.g., Li and Yang 2016) that use mandatory (voluntary) IFRS adopters as the treatment (control) firms, we use late RF disclosers (i.e., firms that began to provide RF disclosures after the mandate) as the treatment firms, and early RF disclosers (i.e., firms that voluntarily provided RF disclosures before the mandate) as the control firms. ${ }^{7}$ We use early RF disclosers as the control group because they provide a similar amount of RF disclosure before and after the 2005 mandate (consistent with Nelson and Pritchard 2016; Section 4.1 provides details) and thus are much less affected by the mandate relative to late RF disclosers. The results of our analyses suggest that the RF mandate encourages firms to take on more litigation risk in providing forward-looking information. Specifically, we find that compared to early RF disclosers, late RF disclosers provide a larger amount of FLSs in the Management's Discussion and Analysis (MD\&A) section of their 10-K filings after 2005 than they did previously. The tone of their FLSs is also more optimistic, primarily due to an increase in positive FLSs rather than a decrease in negative FLSs. In addition to the DiD analysis, we follow Petacchi (2015) and use a two-stage least squares (2SLS) model to confirm that the RF mandate is a strong enough shock to RF disclosure to affect managers' perceived litigation risk, and that the mandatedriven increase in the amount and specificity of RF disclosure explains the change in FLSs.

We further examine whether the positive FLSs induced by the 2005 RF mandate are informative for investors. This is not a given, since late RF disclosers might perceive a higher level of safe harbor protection as a "license to lie" (Senate Report 1995; Horwich 2010; Olazabal 2011). We first use the same DiD design and find that the information environment of the late RF disclosers improves after the $2005 \mathrm{RF}$ mandate, compared to that of the early RF

\footnotetext{
${ }^{7}$ Before the RF mandate, firms could choose not to provide risk factors for reasons such as proprietary costs (Verrecchia 1983; Ellis et al. 2012; Hope et al. 2016; Israelsen and Yonker 2017; Ernst and Young 2018), cost of capital concerns (Kravet and Muslu 2013; Campbell et al. 2014; Filzen 2015; Heinle et al. 2018; Beatty et al. 2019), or preparation costs (Austin and Bernard 2016; Wachtell et al. 2016; Gelfond et al. 2018; McClane 2019). Section 2.1 provides a detailed discussion.
} 
disclosers. Because RF disclosure itself is informative to the market (Campbell et al. 2014; Filzen 2015; Hope et al. 2016), we conduct a path analysis that separates the source variable's direct and indirect impact on an outcome variable. Our results reveal that the 2005 RF mandate improves the late RF disclosers' information environment both directly, through additional RF disclosure, and indirectly, through the mechanism of inducing more disclosure of positive FLSs. This finding mitigates the concern that managers use safe harbor provision as a "license to lie" (Senate Report 1995; Horwich 2010; Olazabal 2011) and, more importantly, indicates that the $2005 \mathrm{RF}$ mandate provides an unintended economic benefit.

Finally, we conduct a series of tests to examine the cross-sectional variation in the impact of the RF mandate and provide further evidence that the mandate induces more FLSs because of its legal implication. Intuitively, if the RF mandate affects FLSs through managers' perception of legal protection, its effect should be stronger when firms' FLSs are more likely to be targeted in lawsuits, when meaningful cautionary statements have a greater impact on lawsuit outcomes, and when managers are more familiar with the role of meaningful cautionary statements in lawsuits. We find evidence supporting all three of these intuitions. First, consistent with the evidence that securities class action lawsuits are more likely to target FLSs that turn out to be overly optimistic (Rogers et al. 2011), the RF mandate's effect on FLSs is stronger for firms that are more susceptible to large unexpected negative events - that is, firms with more volatile earnings, firms in more competitive industries, and firms with higher R\&D investments. Second, we explore the variation in the legal protection of risk factors within the judicial system. Using the ideology of federal judges in the circuit court that has jurisdiction over the state where a firm is headquartered, we measure how pro-plaintiff the court is (Huang et al. 2019). We find that when firms face a more pro-plaintiff court and thus have a higher need for meaningful cautionary language for their legal defense, the RF mandate has stronger effects. Finally, we expect managers who have experienced securities litigations in the past to be more aware of the legal protection of risk factors. Consistent with this intuition, we find that the RF mandate's effect on FLSs is stronger for firms that have been previously sued by shareholders. Overall, our cross-sectional analyses find supporting evidence that the 2005 RF mandate affects firms' FLSs by changing managers' perception of litigation risk.

We contribute to the literature in several ways. First, we focus on the legal implications of the RF mandate, an aspect unexplored in the literature on RF disclosures. By documenting that the RF mandate spurs voluntary forward-looking disclosure, which in turn improves firms' information environment, we help paint a more complete picture of the total impact of the mandate. Our findings also explain the controversy surrounding this disclosure regulation-that is, although regulators intend to supply investors with information about firm risk, firms prepare RF disclosures in a manner that exploits their legal benefits. This incentive leads firms to include large, seemingly boilerplate passages in their filings and prompts them to provide more forward-looking information. As Leuz and Wysocki (2016) note, regulatory consequences or the desirability of regulation is 
a complex issue due to the various costs and benefits that arise from regulation. Our insight cautions against drawing conclusions exclusively from the information content of RF disclosures and can help to guide the development of future disclosure regulations.

Second, we contribute to the literature on litigation risk by identifying a specific mechanism that changes managers' perception of such risk, which is notoriously difficult to capture (Lowry 2009; Marinovic and Varas 2016). To measure managers' perception of litigation risk, previous studies use legal regimes, judge ideology, court precedents, past lawsuits, industry membership, and firm characteristics such as size and past stock return volatility (Francis et al. 1994; Johnson et al. 2001; Rogers and Van Buskirk 2009; Kim and Skinner 2012; Huang et al. 2019; Franke et al. 2021). In our setting, when managers, with help from their legal counsel, prepare and disseminate RF disclosures, they get a clear sense of how disclosure of certain risk factors might provide them with safe harbor protection, which lowers their perceived litigation risk when they provide FLSs (Olazabal 2011).

Finally, we contribute to research that examines managers' decisions to provide forward-looking qualitative disclosures. Studies show that despite the passage of the PSLRA, such disclosures are the prime target of plaintiff complaints (Rogers et al. 2011; Cazier et al. 2020) and lead to adverse litigation outcomes (Cutler et al. 2019), which calls into question the legal protection afforded by the safe harbor provision. We extend this stream of research by documenting that the provision of meaningful cautionary language is an important determinant of managers' perceived strength of safe harbor protection and increases their willingness to disclose qualitative FLSs.

\section{Background, literature, and hypothesis development}

\subsection{The PSLRA, the safe harbor provision, and meaningful cautionary language}

Congress enacted the PSLRA to encourage firms to disclose more forward-looking information. Before the PSLRA, managers were reluctant to disclose any FLSs for fear of being sued by shareholders if their predictions turned out to be wrong. The PSLRA addresses this fear by providing litigation immunity-the safe harbor provision-for FLSs that are "accompanied by meaningful cautionary statements identifying important factors that could cause actual results to differ materially from those in the forward-looking statement" (15 USC $\S \S 77 \mathrm{z}-$ 2(c)(1)(A)(i)). This provision can significantly lower companies' litigation costs by facilitating the dismissal of plaintiff challenges at the pleading stage-before the costly and time-consuming discovery process (i.e., the Stay of Discovery, 15 USC $\S \S 78 u-4(b)(3)(b))$.

Since the enactment of the PSLRA, judicial decisions on whether the safe harbor provision should apply in lawsuits related to FLSs often hinge on the cautionary language. Judges take a hard look at this language and dismiss plaintiffs' complaints only if it is truly meaningful (Ericson and Kinser 2015). Although the PSLRA does not provide an explicit definition of meaningfulness, legislative 
history and court decisions provide some guidance. During the passage of the PSLRA, Congresswoman Eschoo stated, "There is no liability for forward-looking statements as long as these statements are accompanied by specific warnings that their predictions may not come true" (141 Congressional Record 35,569 (1995)). Courts usually require that cautionary language be specific, updated, and tailored to the risks of the projections to trigger the safe harbor provision. ${ }^{8,9}$

Meeting these criteria is not a trivial task and can lead to substantial costs for firms. First, disclosing detailed "warnings," such as specific risks a firm faces with its supply chain, important customers, key personnel, or product development, can inform and benefit competitors and thus carries significant proprietary costs (Verrecchia 1983). In a guide for preparing annual reports, Ernst \& Young (2018) cautions clients to consider "the risk of significant competitive harm" when disclosing risk factors. Researchers find that firms with higher proprietary costs disclose less specific risk factors in general (Hope et al. 2016), and that proprietary cost is an important determinant of whether firms disclose large customers (Ellis et al. 2012) or key employees (Israelsen and Yonker 2017), which are common RF topics (Campbell et al. 2014). Second, the disclosure of risk factors can increase the firm's risk as assessed by the market and thus the firm's cost of capital (Heinle et al. 2018). Consistent with this prediction, studies show that the market reacts negatively to the disclosure of new risk factors (Kravet and Muslu 2013; Campbell et al. 2014; Filzen 2015; Beatty et al. 2019). Furthermore, the firm must expend a great deal of time and effort to detail its risk factors, especially factors that are tailored enough and specific enough to qualify as meaningful cautionary statements (Austin and Bernard 2016; Wachtell et al. 2016; McClane 2019). The RF section is usually one of the longest in 10-Ks (Dyer et al. 2017), constituting 12\% of the 10-K's length on average (Section 4.1 provides details). Keenly aware of the role of risk factors in providing legal protection, Gelfond et al. (2018) advise legal counsels to tailor RF disclosure to the specific company, to talk to not only top management but also people with different specialties within the company, to review the risk factors of competitors, and to consider the significance and probability of each risk.

Despite the substantial costs of preparing and disclosing sufficiently meaningful cautionary statements, some companies voluntarily disclosed risk factors before the

\footnotetext{
${ }^{8}$ For example, in Julianello v. K-V Pharmaceutical Co. 791 F.3d 915 2015, the 8th Circuit dismissed the lawsuit, concluding that K-V Pharmaceutical's statement fell within the PSLRA's safe harbor provision. The court credited the company's RF disclosure in its 2010 10-Ks, stating that "[c]autionary language must be extensive, specific, and directly related to the alleged misrepresentation." However, the D.C. Circuit declined safe harbor protection in Re: Harman International Industry Inc. Securities Litigation (D.C. Circuit, June 23, 2015), holding that the company's precautionary language was too general.

9 A cautionary statement that does not change over time (i.e., repeatedly included in 10-Ks) can still offer legal protection to firms' FLSs. For example, when granting the motion to dismiss in Arkansas Teacher Retirement System, et al. v. Monsanto, federal circuit court judge Catherine Perry wrote in her order, "I am also not persuaded by plaintiff's argument that defendants' cautionary language is not meaningful simply because it 'remained virtually unchanged' during the relevant time period. While some of the language used in Monsanto's public filings was similar, the warnings were specific to Monsanto's business and were indeed the very risks that, according to plaintiff, caused Monsanto to miss its targeted projections" (Docket \# 10-CV-01380 Memorandum and Order, filed on August 1, 2012).
} 
mandate in order to avail themselves of the safe harbor provision (SEC 2004). ${ }^{10}$ Others chose not to disclose risk factors, and avoided lawsuits by providing few FLSs or more conservative discussions about future operations (Rogers and Van Buskirk 2009).

\subsection{The 2005 RF mandate}

To improve the 10-K's informativeness, the SEC began mandating the disclosure of "the most significant factors that make an investment in a registrant's securities speculative or risky," in a new section of the 10-K (Item 1A, titled "Risk Factors"), from December 1, 2005, onward (item 503(c) of Regulation $\mathrm{S}-\mathrm{K}) .{ }^{11}$ The regulation stipulates that risk factors must be specific to firms and "explain how the risk affects the issuer or the securities." Since the mandated RF disclosures might qualify as meaningful cautionary statements under the PSLRA, firms that began to provide RF disclosure could now invoke the safe harbor provision for their FLSs (Hazen 2011; White 2013; Shearman and Sterling 2014). In numerous class action lawsuits, district and circuit courts have upheld RF disclosures as being sufficient to meet the requirements of meaningful cautionary language. ${ }^{12}$ Thus, it is not surprising that despite the RF mandate's stated intention to prompt firms to provide information about their risks, firms write RF disclosures in a manner that is designed to minimize legal risk rather than to maximize informativeness (Brusch and McGough 2016). The firms' emphasis on legal protection explains why investors often complain that RF disclosures "do not provide clear, concise and insightful information" (IRRC Institute 2016). Meredith Cross, the director of the SEC's Division of Corporate Finance, pointedly comments that RF disclosures have become "mind-numbing" and are in need of fixing (Johnson 2010). ${ }^{13}$ Such concerns

\footnotetext{
${ }^{10}$ In the RF mandate proposal, the SEC states, "We note that many issuers have included risk factor disclosure in their Exchange Act reports for a number of years. See comment letter in File No. S7-30-98 from the Business Roundtable. Issuers may already include risk factor disclosure in their Exchange Act reports for varying reasons, including to take advantage of the safe harbor for forward looking statements in Securities Act Section 27A and the bespeaks caution defense developed through case law" (SEC 2004).

11 Before the 2005 mandate, firms were only required to disclose risk factors in their initial public offering (IPO) prospectus.

12 For example, in Re: LeapFrog Enterprises, Inc. Securities Litigation, federal district court judge Ronald M. Whyte of the Northern District of California found reference to the "Risk Factors" section of the defendant's 10-K and 10-Q to suffice as meaningful cautionary language (Page 15, No. C-03-05421 RMW, Order Granting Defendants' Motions to Dismiss, filed on September 30, 2007). Other district and circuit court cases in which judges considered risk factors in 10-Ks as meaningful cautionary language to invoke the safe harbor provision and dismissed lawsuits include Re: Clorox, US Court of Appeals, 9th Circuit, 2004; Re: Ibis Technology Securities Litigation, US District of Massachusetts, 2006; Re: Humana, Inc. Securities Litigation, US Western District of Kentucky, 2009; and Julianello v. K-V Pharmaceutical Company, US Court of Appeals, 8th Circuit, 2015.

13 Practitioners express similar views. In a comment letter to the SEC, the law firm Wachtell, Lipton, Rosen, and Katz states, "Many companies feel compelled to sacrifice usefulness and accessibility in favor of protection from legal risk through overdisclosure and standardized disclosure such as "boilerplate' risk factors. Such overdisclosure not only burdens corporate resources-at the expense of shareholders-but often buries shareholders in an avalanche of information that ultimately limits the practical utility of Exchange Act filings" (Wachtell et al. 2016).
} 
have led two former SEC chairwomen, Mary Schapiro and Mary Jo White, to call for a cost-benefit analysis of the mandate (Johnson 2010; White 2013).

\subsection{RF disclosure research}

A number of studies examine the usefulness of the information provided in firms' RF disclosures. Campbell et al. (2014) find that the amount of RF disclosure provided by a firm is positively correlated with the firm's fundamental risk and the market's assessment of that risk. Hope et al. (2016) show that the market's reaction to $10-\mathrm{K}$ filings increases with the specificity of a firm's RF disclosure. Similarly, Kravet and Muslu (2013) find that RF disclosure reflects market-based measures of risk.

However, some evidence shows that the mandate has reduced the usefulness of information to investors. Nelson and Pritchard (2016) find that RF disclosures reflect firms' systematic and idiosyncratic risk in the voluntary regime but not in the mandatory regime. They find that after the mandate, low- and high-risk firms provide RF disclosure of similar quality, and that the mandatory RF disclosures of low-risk firms convey little useful information. They conclude that although the mandate has led to a substantial convergence in RF disclosure, it has not increased the amount of useful information for investors. Similarly, Beatty et al. (2019) find that although the length of RF disclosures has increased, the association between RF disclosure length and a firm's underlying risk has decreased since the financial crisis and since firms have started receiving SEC comment letters.

\subsection{Hypothesis development}

In contrast to studies that focus on the information content of RF disclosures, we focus on the 2005 RF mandate's effect on managers' perceptions of litigation risk and their subsequent decisions to issue voluntary FLSs. We argue that after the mandate, managers perceive a reduction in litigation risk associated with providing FLSs, for two reasons. First, RF disclosure can lower litigation costs if the firm is sued by its shareholders. As discussed in Section 2.2, the mandated RF disclosures are similar to the meaningful cautionary language of the PSLRA (e.g., the PSLRA's conference committee report 1995; SEC 2004; Nelson and Pritchard 2007; Olazabal 2011). Thus, after the RF mandate, managers might believe that if their firm is sued by its shareholders for misleading FLSs, courts are more likely to dismiss the lawsuit because of the PSLRA's safe harbor provision (Coffee 1996; Horwich 2010; Shearman and Sterling 2014; McCann 2018). Second, RF disclosure can reduce the tendency of shareholders and their attorneys to bring lawsuits against the firm. Investors are less likely to feel wronged and entitled to financial compensation when FLSs are accompanied by cautionary disclaimers (Asay and Hales 2018), and thus are less likely to sue the firm. Plaintiffs' attorneys, who stand to receive millions or even billions of dollars, get paid on a contingent-fee basis only (Fitzpatrick 2010). That is, they must 
first work hundreds or thousands of hours on a case without compensation and are only awarded attorney fees if and when they prevail in court or when the defendants agree to settle (Baker et al. 2015). Not surprisingly, plaintiffs and their attorneys are less likely to file lawsuits when they perceive a lower chance of prevailing (de Figueiredo 2005).

According to the risk compensation literature, when agents perceive greater safety (i.e., reduced risk), they exhibit riskier behavior (Hedlund (2000) provides a review). For example, Peltzman (1975) shows that people drive faster after regulations require manufacturers to install safety devices, such as seat belts, on automobiles. Similarly, Phillips et al. (2011) find that cyclists ride faster when they are required to wear a helmet. In the economic sphere, DeLong and Saunders (2011) and Calomiris and Jaremski (2019) find that banks increased their risk-taking behavior after the introduction of deposit insurance in the early twentieth century. In our setting, risk compensation theory predicts that if managers perceive lower litigation risk after the 2005 mandate, they will be more willing to take litigation risk in providing forward-looking disclosure.

However, it is possible that the 2005 RF mandate does not reduce managers' perceived litigation risk sufficiently to result in an increase in firms' FLSs. There are two reasons for this. First, whether courts interpret RF disclosures as meaningful cautionary language is uncertain (Pritchard and Sale 2005; Horwich 2010; Olazabal 2011). Even if judges consider the risk factors, they might refuse to dismiss lawsuits on the grounds of the safe harbor provision if they find that the cautionary language is not pertinent to the allegation. ${ }^{14}$ Thus, managers might not view RF disclosures as being reliable in reducing litigation costs. Second, the RF mandate only affects firms that did not voluntarily provide risk factors before the mandate and these firms might not expect a large legal benefit from the safe harbor provision. Presumably, in the pre-mandate period, these firms chose not to provide RF disclosures because the legal benefit of doing so was less than the cost. For example, they may have disclosed FLSs but avoided securities litigation even without the safe harbor provision due to a track record of consistently meeting their projections; or they may not have provided FLSs for reasons unrelated to litigation risk, such as high proprietary costs or complex business operations that made FLSs difficult to forecast (Verrecchia 1983; Waymire 1985). Because their FLS decision is driven by non-litigation-risk concerns, these firms might not increase their FLSs despite the lower perceived litigation risk after the mandate. Taken together, whether the 2005 mandate leads to an increase in voluntary disclosure practices among late RF disclosers is an empirical question.

Intuitively, when firms are more willing to take litigation risk in providing FLSs, they disclose a larger amount of FLSs. Furthermore, optimistic statements carry a significantly higher litigation likelihood and lead to larger shareholder damage in

\footnotetext{
14 For example, the D.C. Circuit court ruled that safe harbor protection did not apply in Re: Harman International Industry Inc. Securities Litigation (D.C. Circuit, June 23, 2015). The court held that the company's $10-\mathrm{K}$ risk factors were too general because they "spoke generally of 'products,' both 'existing' and 'new,", and "were not tailored to the specific forward-looking statement the Company made (which is that 'sales of aftermarket products, particularly PNDs, were very strong')."
} 
lawsuits than pessimistic statements do (e.g., Skinner 1997; Cao and Narayanamoorthy 2010; Rogers et al. 2011; Cutler et al. 2019). ${ }^{15}$ Thus, we hypothesize the following:

H1: Late RF disclosers increase the amount of FLSs, particularly positive ones, after the 2005 RF mandate, compared to early RF disclosers.

Even if late RF disclosers provide more positive FLSs following the mandate, it is unclear whether these additional FLSs are informative for investors. On the one hand, the SEC has long recognized the investor demand for FLSs and has encouraged and guided companies to provide FLSs in the MD\&A section of 10-K filings (SEC 1989, 2003, 2020; Levitt 1996). ${ }^{16}$ Studies note the benefits of forward-looking disclosure in general (see review by Core 2001; Healy and Palepu 2001; Leuz and Wysocki 2016). In particular, Li (2010) and Muslu et al. (2015) find that FLSs in the MD\&A section disclose information about a firm's future performance, such as its earnings and liquidity, and mitigate the potential mispricing of accruals. On the other hand, a concern raised during the passage of the PSLRA is that firms might use the safe harbor provision as a "license to lie," because it might offer protections even when managers make knowingly false projections (141 Congressional Record 1995; Levitt 1995; Senate Report 1995; Coffee 1996; Horwich 2010; McCann 2018). ${ }^{17}$ Managers generally have incentives to make optimistic disclosures. For example, studies find that managers sometimes positively bias their voluntary disclosures to lower the cost of capital, cover up earnings management, or increase their own compensation (Aboody and Kasznik 2000; Lang and Lundholm 2000; Huang et al. 2013). If late RF disclosers perceive higher legal protection after the 2005 RF mandate, they might feel free to provide intentionally or unintentionally false FLSs, which can worsen their information environment. This tension leads to our next hypothesis:

H2: The information environment of late RF disclosers improves relative to that of early RF disclosers after the $2005 R F$ mandate due to an increase in positive FLSs.

In addition to the mandate's average effect on forward-looking disclosure, we examine the variation in the strength of this effect to provide further support for the mechanism through which the mandate affects forward-looking disclosure. As the 2005 RF mandate induces more FLSs due to managers' perception of legal

\footnotetext{
${ }_{15}$ Litigation risk also encourages companies to preempt bad news (Skinner 1994). However, as the safe harbor provision's intention is to provide protection for overly optimistic forecasts, we focus on good news rather than bad news or the overall news level (Bao et al. 2019; Houston et al. 2019; Naughton et al. 2019).

16 In its 1989 MD\&A Interpretive Release, the SEC states that the general purpose of the MD\&A is to "provide both a historical and prospective analysis of the registrant's financial condition and results of operations, with particular emphasis on the registrant's prospects for the future" (SEC 1989).

17 Some judges call the safe harbor provision "a curious statute, which grants (within limits) a license to defraud" (in Re: Stone \& Webster, Inc. Securities Litigation, 414 F.3d 187, 212, 1st Circuit, 2005). Consistent with this view, courts have ruled that intention is irrelevant for safe harbor protection. See, for example, Re: Harris v. IVAX Corp., 182 F.3d 799,808 (11th Circuit, 1999) and Re: Miller v. Champion Enterprises, 346 F.3d 660,672 (6th Circuit, 2003).
} 
protection, the effect should be stronger when managers perceive a higher level of legal benefit from meaningful cautionary statements, such as when firms' FLSs are more likely to be the target of lawsuits. Hence, we make the following prediction:

H3: The increase in the amount of positive FLSs from late RF disclosers after the $2005 R F$ mandate is greater for firms whose managers perceive a higher level of legal benefit from meaningful cautionary statements.

\section{Sample and variable measurement}

\subsection{Sample}

To test our hypotheses, we obtain firms' 10-K filings from the SEC's Edgar database, their financial data from Compustat, and their stock price data from the Center for Research in Security Prices (CRSP). We use the 10-K filings in the following two periods: 2000-2004 and 2006-2010 (i.e., five years before and five years after the effective date of the RF mandate). ${ }^{18}$ We exclude Compustat fiscal year 2005 from the sample period because the mandate took effect for fiscal years ending after December 1, 2005, and affected firms with a fiscal year-end from December 2005 to May 2006 but not others (i.e., firms with a fiscal year-end from June to November 2005). ${ }^{19}$ Before the mandate, some firms voluntarily disclosed risk factors, usually in Item 1 (Business) of their 10-K filings. ${ }^{20,21}$ Beginning in 2005 , it was required that RF disclosures be provided in Item 1A (503(c) of Regulation S-K). We define a firm as an early RF discloser if it disclosed risk factors in the pre-mandate period (January 1, 2000, to December 1, 2005) and as a late RF discloser if it did not. To determine whether a firm disclosed risk factors before the mandate, we search for RF-related phrases in its 10-K filings (Section 4.1 provides details).

\footnotetext{
18 All of the years used in the empirical tests are fiscal years. In the robustness tests, we use one-, two-, and four-year windows around 2005 (i.e., 2004 and 2006; 2003-2004 and 2006-2007; and 2001-2004 and 2006-2009, respectively) as the pre- and post-event windows and find similar results. As the RF mandate was first proposed by the SEC on November 3, 2004, we rerun our analyses using January 1, 2000, to October 31, 2004, as the pre-event window and 2006-2010 as the post-event window. We find similar results. Section 4.6.2 discusses these results (tabulated in Internet Appendix Table IA1).

19 In a robustness test, we classify the 2005 sample into pre- and post-mandate periods based on whether the firms' 2005 fiscal year ended before or after December 1, 2005, respectively, and find similar results. Section 4.6.2 discusses these results (tabulated in Internet Appendix Table IA1).

20 Before 2005, the majority of early RF disclosers disclosed their main risk factors in Item 1 (Business) and referred to them using phrases such as "risk factor," "business risk," "factors that may affect future results," and "factors affecting future performance," with the rest in Item 7 (MD\&A). Note that it is unlikely that risk factors in MD\&A of early RF disclosers drive our results on FLSs' tone and the amount of positive FLSs because risk factors predominately contain negative sentiments (Campbell et al. 2014). In a sensitivity test, we exclude risk-factor-related FLSs in the MD\&A for early RF disclosers and find similar results (tabulated in Internet Appendix Table IA1).

21 In addition, all firms have been required to disclose market risk in Item 7A since 1997 (Item 305 of Regulation S-K). Market risk specifically refers to economic losses due to adverse changes in the fair value of a financial instrument (SEC 1997a) and is not part of Item 1A.
} 
Our main analysis focuses on firms that we can identify as late or early RF disclosers from 2000 to 2005 and their 35,641 10-K filings during the sample periods (2000-2004 and 2006-2010). We remove 10-Ks in which we cannot find an MD\&A section or that lack the necessary financial data in Compustat and CRSP. This requirement reduces the sample size to 23,709 . We further exclude smaller reporting companies, as they are exempt from the RF mandate. ${ }^{22}$ We obtain a final sample of 21,455 firm-year observations for 4410 unique firms. Some of our empirical tests require variables constructed using analyst forecasts from First Call and thus have different sample sizes.

\subsection{Variable measurement}

In this section, we define the main variables used in our analyses. To measure forward-looking disclosure, we use the amount and tone of FLSs in the firms' 10-K MD\&A section. Following Li (2010), we define FLSs as sentences that contain one or more of the following words: "will," "should," "can," "could," "may," "might," "expect," "anticipate," "believe," "plan," "hope," "intend," "seek," "project," "forecast," "objective," and "goal.",23,24 To measure the amount of FLSs, we use the natural log of one plus the number of words in the FLSs (FLS_Amt). To measure the tone of a firm's FLSs (i.e., the level of textual optimism), we use the natural log of one plus the number of positive words scaled by the number of negative words (FLS_Tone). ${ }^{25}$ To identify positive and negative words, we use the word list constructed by Loughran and McDonald (2011).

\section{Empirical analyses}

\subsection{Validating the assumptions of the DiD analyses}

We use a DiD research design to test $\mathrm{H} 1$ - that late $\mathrm{RF}$ disclosers provide more FLSs, particularly positive ones, after the 2005 RF mandate, relative to early RF

\footnotetext{
${ }^{22} \mathrm{RF}$ disclosures are not required for smaller reporting companies-firms with a public equity float of less than US\$75 million (SEC Release Nos. 33-8876 "Smaller reporting company regulatory relief and simplification").

${ }^{23}$ Following Li (2010), we exclude sentences that consist of all capital letters, sentences containing words that are almost certain to be legal boilerplate (such as "undersigned," "herein," "hereafter," "hereof," "hereon," "hereto," "theretofore," "therein," "thereof," and "thereon"), and sentences that contain "expected," "anticipated," "forecasted," "projected," or "believed" when words such as "was," "were," "had," and "had been" follow, because these sentences typically indicate information that is not forward looking in nature.

${ }^{24}$ In a robustness test, we follow Muslu et al. (2015) and use an alternative measure of FLSs that relies more on phrases identifying time (such as "future," "next fiscal," and "upcoming period") and that refers to a year subsequent to the filing year. We find similar results (tabulated in Internet Appendix Table IA2).

25 In a sensitivity test, we use an alternative definition of tone (i.e., the natural log of one plus the number of sentences with positive sentiment, scaled by the natural log of one plus the number of sentences with negative sentiment) following Huang et al. (2014) and find similar results (tabulated in Internet Appendix Table IA3). A sentence is defined as having positive (negative) sentiment if it has more positive (negative) words than negative (positive) words.
} 
disclosers. We compare the change in the forward-looking disclosure behavior of late RF disclosers from the pre-2005 period to the post-2005 period with that of early RF disclosers. ${ }^{26}$

We classify firms as early RF disclosers or late RF disclosers in two steps. First, we search for phrases that indicate that a firm might have disclosed risk factors in its 10-K filings during the pre-mandate period from January 1, 2000, to December 1, 2005. To construct the list of phrases, we read a random sample of 100 RF disclosures in the 10-K filings from the pre-mandate period. The list of phrases includes "risk factor," "cautionary statement," "private securities litigation reform act," "business risk," "forward-looking statement," "forward looking statement," "factors that may affect future results," and "factors affecting future performance." 27 Next, we search for these phrases in the $10-\mathrm{K}$ filings from our pre-mandate period and read each filing that contains such phrases to determine whether they actually are RF disclosures. Of the 22,023 10-Ks from 2000 to 2005, 10,037 have RF disclosures, which belong to 3084 early RF disclosers. ${ }^{28}$ We classify the remaining sample of 1326 firms (i.e., firms that did not have RF disclosures in their pre-mandate $10-\mathrm{K}$ filings) as late RF disclosers.

One assumption of the DiD research design is that early RF disclosers (control firms) experience a smaller increase in legal protection for FLSs after the 2005 RF mandate than late RF disclosers (treatment firms). We provide two pieces of evidence to support this assumption. First, early RF disclosers have similar levels of legal protection for FLSs in both periods due to their pre-mandate RF disclosures, whereas late RF disclosers receive legal protection for FLSs only after the mandate. We verify that the post-2005 RF disclosures of early disclosers are of the same length as their pre-2005 disclosures. Their RF disclosure length, on average, is $12.41 \%$ and $12.14 \%$ of their 10 -K filings in 2005 and 2004, respectively, which is not statistically different. Our finding is consistent with that of Nelson and Pritchard (2016) and suggests that the pre-2005 RF disclosures of early disclosers satisfy the RF mandate. In contrast, late RF disclosers began disclosing their risk factors only in 2005. Their RF disclosure length, on average, was $9.74 \%$ of their 10 -K filings that year. Second, late RF disclosers' post-mandate RF disclosures have similar qualities to those of early RF disclosers. The SEC scrutinizes firms' RF disclosures and sends comment letters, asking for more details, to firms whose disclosures are deemed too

\footnotetext{
${ }^{26}$ Our research design here is similar to that of studies that compare mandatory and voluntary IFRS adopters to examine the impact of IFRS adoption (e.g., Li and Yang 2016).

27 It was common for an early RF discloser to explain that it provided risk factors as cautionary statements accompanying its FLSs under the PSLRA, and to use phrases such as "cautionary statement," "private securities litigation reform act," "forward-looking statement," and "forward looking statement." For example, CenturyLink, Inc., provided an RF disclosure in Item 1 of its 2001 10-K after the following statement: "The Company's forward-looking statements, and the assumptions upon which such statements are based, are subject to uncertainties that could cause the Company's actual results to differ materially from such statements. These uncertainties include but are not limited to those set forth below..."

28 The average length of the RF disclosure section in the 2000-2004 period is 3820 words. As discussed in Section 2.1, to qualify for the safe harbor provision, risk disclosures must be sufficiently specific and detailed (Schaffer v. Evolving Systems, Inc., 29 F. Supp. 2d 1213, 1224 (D. Colo. 1998)). Among the 10,882 10-Ks that have RF disclosures, we remove 845 10-Ks with RF disclosures of less than 500 words. A reading of these 845 short RF disclosures reveals that they are too short and general to qualify as meaningful cautionary language. Our results are robust to their inclusion in the sample.
} 
generic (Campbell et al. 2014; Brown et al. 2018). We find that after 2005, late RF disclosers are as likely to receive SEC comment letters about risk factors as early RF disclosers, which indicates that the two groups provide RF disclosures of similar quality (not tabulated). ${ }^{29}$ This finding is consistent with that of Nelson and Pritchard (2016), who show that the informativeness of the RF disclosures provided by early and late RF disclosers is not statistically different after the 2005 mandate. Overall, the evidence confirms that late RF disclosers experience a significant increase in legal protection after 2005, whereas early RF disclosers do not. ${ }^{30}$

\subsection{Changes in FLSs due to the 2005 RF mandate}

We test H1 (i.e., whether late RF disclosers provide more FLSs and more positive FLSs after 2005 relative to early RF disclosers) using the following regression:

$$
\text { FLS_Amt(FLS_Tone, FLS_Pos })=\alpha+\beta_{1} \text { LateRF }+\beta_{2} \text { LateRF } \times \text { Post }+\gamma \text { Controls }+\varepsilon,
$$

where the amount and tone of FLSs and the amount of positive FLSs (FLS_Amt, $F L S \_T o n e$, and FLS_Pos, respectively) are the dependent variables; LateRF is an indicator variable that equals one for late RF disclosers and zero for early RF disclosers; and Post is an indicator variable that equals one in the post-2005 period, and zero otherwise. ${ }^{31}$ Following $\mathrm{Li}$ (2010), we control for other determinants of voluntary disclosure (Controls): profitability (ROA), past stock returns (RET), accruals (Accruals), firm size (Size), market-to-book ratio (MtoB), return volatility (RetVol), earnings volatility (EarnVol), special items (SPI), firm age (FirmAge), business complexity measured by the number of business and geographic segments (SEG_Bus and $S E G_{-} G e o$ ), and Delaware incorporation $(D E)$. To control for time trends in disclosure and other unobservable time-invariant industry or firm characteristics that might affect voluntary disclosure, we include year fixed effects and alternatively industry and firm fixed effects in the model. We provide detailed variable definitions in the Appendix. All of the $t$-statistics are based on standard errors clustered at the firm level.

In Eq. (1), $\beta_{1}$ captures the average difference between the forward-looking disclosures of the late and early RF disclosers before the mandate. Our coefficient of interest is $\beta_{2}$, which captures the average difference between the change in the forwardlooking disclosure behavior of the late and early RF disclosers from the pre-mandate period to the post-mandate period. H1 predicts a positive coefficient of $\beta_{2}$. That is,

\footnotetext{
${ }^{29}$ In a robustness test, we remove firm-years in which the firm receives SEC comment letters related to risk factors and find similar results (tabulated in Internet Appendix Table IA4).

${ }^{30}$ The DiD model also requires an assumption of parallel trends in which the average outcomes for the treatment and control groups follow parallel paths before the shock affects the treatment group. To verify this assumption, we compare the pre-mandate forward-looking disclosure trends for the treatment and control groups. The results (untabulated) show that in the pre-mandate period, the average growth rate in the treatment group's FLS amount is $15.07 \%$, which is not statistically different $(t$-stat $=0.51)$ from that of the control group (15.71\%).

${ }_{31}$ We do not separately include POST because it would be subsumed by year fixed effects. In a sensitivity test, we include POST as a control variable and omit year fixed effects. The results for the main variable (LateRF $\times$ Post) remain similar (tabulated in Internet Appendix Table IA5).
} 
we expect late RF disclosers to exhibit a greater increase than early RF disclosers in both the amount and optimism of their forward-looking disclosures after the RF mandate.

Panel A of Table 1 reports the summary statistics of the dependent and control variables. Panel B of Table 1 compares the firm characteristics of the late and early RF disclosers in 2004, the year before the RF mandate. The late RF disclosers are larger, older, more profitable, and less likely to be incorporated in Delaware than the early RF disclosers. They also have higher accruals, more geographic segments, higher stock returns, lower market-to-book ratios, lower return volatility, and lower earnings volatility. In a sensitivity test, we use a propensity score matched sample in which each late RF discloser is matched with an early RF discloser based on firm characteristics in 2004, and find similar results (tabulated in Internet Appendix Table IA6; Section 4.6.1 provides a detailed discussion).

In Table 2, we report the results of the univariate analysis of the differences between the changes in the FLSs for the late and early RF disclosers. We present the statistics for the late and early RF disclosers in Columns (3) and (6), respectively. The general trends in FLSs are captured in the early RF disclosers, which are not affected by the RF mandate (Column (6)). Their FLSs become longer (FLS_Amt) and more optimistic (FLS_Tone) over time, but their amount of positive FLSs (FLS_Pos) does not change. We present the results of the univariate DiD analysis in Column (7). The results show that the late RF disclosers produce more FLSs and more optimistic FLSs, post mandate, than the early RF disclosers do (DiD coefficients based on FLS_Amt, FLS_Tone, and FLS_Pos are all significant at the 1\% level). Overall, the univariate results indicate that late RF disclosers show a greater willingness to be exposed to litigation risk after the mandate than early RF disclosers do. These results support H1.

Next, we present the results of our Eq. (1) regression in Columns (1) and (3) of Table 3. In this regression, we control for other economic factors and industry fixed effects. Consistent with H1, we find that the estimated coefficients of Lat$e R F \times$ Post are positive and significant at the $1 \%$ and $5 \%$ levels for FLS_Amt and $F L S_{-}$Tone, respectively. This finding indicates that late RF disclosers increase both the amount and level of optimism of their FLSs after the mandate. These increases are economically significant. The results of the regression that uses POST instead of year fixed effects (tabulated in Internet Appendix Table IA5) show that, on average, the late RF disclosers exhibit a $67 \%$ increase in the amount of FLSs-from 1482 words in 2004 to 2479 words post mandate. In contrast, the early RF disclosers only exhibit an $11 \%$ increase in FLSs in the same period-from 2363 words in 2004 to 2627 words post mandate. Our tone results show a similar pattern. On average, the late RF disclosers exhibit a 5.2\% increase in optimism in their FLSs from their 2004 level to their post-mandate average $(0.018+0.024$ scaled by their average FLS_Tone of 0.802 in 2004). In contrast, the early RF disclosers exhibit only a $2.2 \%$ increase over the same period ( 0.018 scaled by their average FLS_Tone of 0.803 in 2004). The estimated coefficients of our control variables show that firms with lower return on assets, more accruals, higher market-to-book ratios, and more special items have more positive FLSs, consistent with the results of previous studies (e.g., Li 2010). 


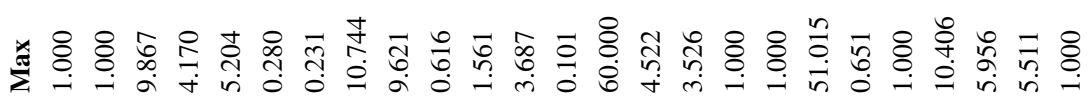

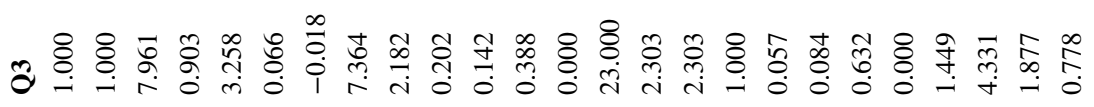

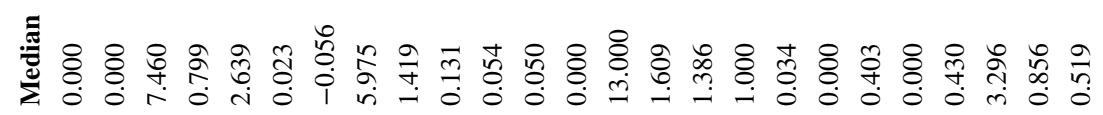

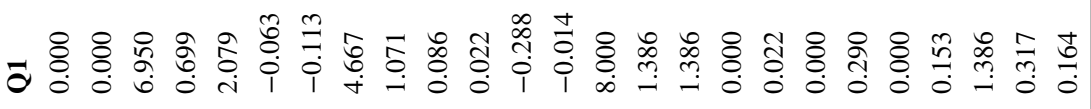

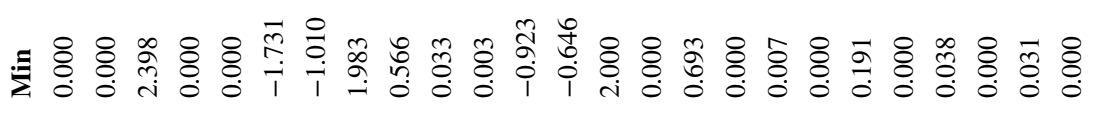

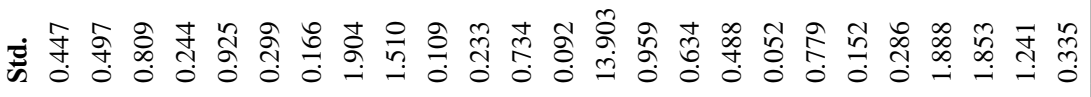

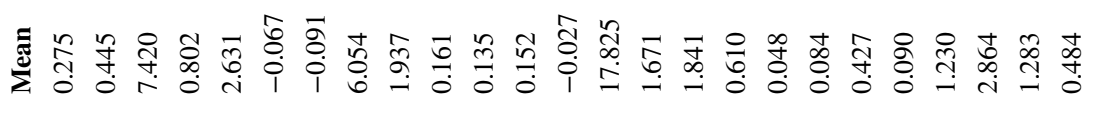

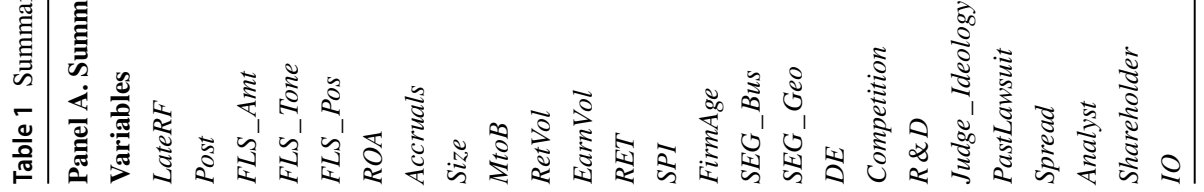




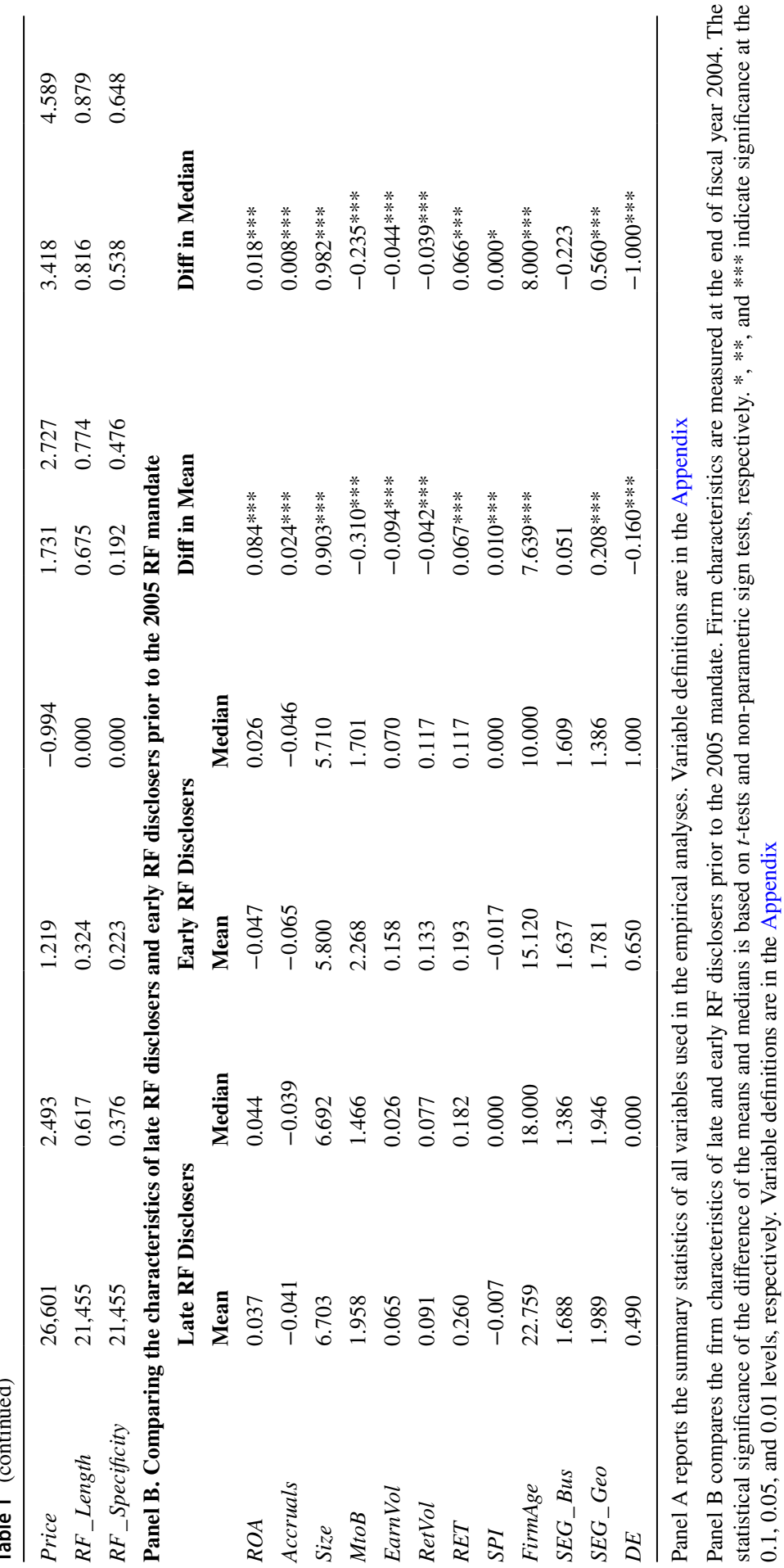


Table 2 Univariate analysis of the changes in forward-looking statements after the 2005 RF mandate

Late RF Disclosers

(1)

$(3)=(2)-(1)$

Early RF Disclosers

Diff-in-Diff

Pre-2005 Post-2005

(4)

(5)

(6) $=(5)-(4)$

$(7)=(3)-(6)$

\begin{tabular}{|c|c|c|c|c|c|c|c|}
\hline & Pre-2005 & Post-2005 & & Pre-2005 & Post-2005 & & \\
\hline$F L S_{-} A m t$ & 6.905 & 7.490 & $0.585 * * *$ & 7.444 & 7.598 & $0.154 * * *$ & $0.431 * * *$ \\
\hline FLS_Tone & 0.777 & 0.819 & $0.042 * * *$ & 0.797 & 0.814 & $0.017 * * *$ & $0.025^{* * *}$ \\
\hline FLS_Pos & 2.085 & 2.660 & $0.576^{* * * *}$ & 2.742 & 2.727 & -0.015 & $0.591 * * *$ \\
\hline
\end{tabular}

This table compares the average amount and tone of FLSs and the amount of positive FLSs in the preand post-2005 mandate periods of late and early RF disclosers. *, **, and *** indicate significance at the $0.1,0.05$, and 0.01 levels, respectively. Variable definitions are in the Appendix

To determine whether this increase in optimism is driven by an increase in the amount of positive FLSs or a decrease in the amount of negative FLSs, we use the amount of positive FLSs, FLS_Pos (i.e., the natural log of one plus the number of positive words in the FLSs of the MD\&A section of the 10-K filings), as the dependent variable. The estimated coefficients of LateRF $\times$ Post are positive and statistically significant at the $1 \%$ level (Column (5) of Table 3). This finding indicates that the increase in optimism among late RF disclosers is driven by a greater willingness to disclose forward-looking good news, which these firms would have withheld had the safe harbor provision arising from the RF disclosures not been present. ${ }^{32}$

To better control for unobservable firm characteristics that might affect voluntary disclosure, we rerun our analyses, replacing industry fixed effects with firm fixed effects. In this specification, we omit two firm invariant control variables, LateRF and $D E$, from the estimation. Although including firm fixed effects in the regression diminishes the explanatory power of some of the control variables (such as Accruals), our main results from Columns (2), (4), and (6) of Table 3 remain consistent. That is, the estimated coefficients of LateRF $\times$ Post ( 0.357 for FLS_Amt, 0.030 for FLS_Tone, 0.490 for FLS_Pos) are statistically significant at the $1 \%$ level. Overall, the results of our regressions support the prediction that late RF disclosers provide a larger amount of, and more optimistic, FLSs after the 2005 RF mandate. This result suggests that they are more willing to take litigation risk.

To examine whether the 2005 RF mandate takes the forward-looking disclosure practice of late RF disclosers to the same level as that of early disclosers, we test whether the level of FLS_Amt, FLS_Tone, and FLS_Pos are different between early and late RF disclosers in the post-mandate period (i.e., we test if $\beta_{1}+\beta_{2}=0$ ). The F-test results (reported in Table 3) indicate that after the RF mandate, early RF disclosers still provide a higher total amount of FLSs than late RF disclosers (significant at the 0.01 level), but the two groups are not different in the tone of their FLSs or in the amount of positive FLSs. These results are consistent with the conjecture

\footnotetext{
32 In Internet Appendix Table IA7, we examine the change in the amount of negative FLSs (FLS_Neg, defined as the natural log of one plus the number of negative words in the FLS in the MD\&A). We find that although the amount of negative FLSs increases for late RF disclosers post mandate, the relative magnitude of its increase is less than that of positive FLSs. Thus, the tone of their FLSs is more optimistic overall.
} 
Table 3 Changes in forward-looking statements after the 2005 RF mandate

\begin{tabular}{|c|c|c|c|c|c|c|}
\hline & $\begin{array}{l}(1) \\
F L S \_A m t\end{array}$ & $\begin{array}{l}(2) \\
F L S \_A m t\end{array}$ & $\begin{array}{l}\text { (3) } \\
\text { FLS_Tone }\end{array}$ & $\begin{array}{l}(4) \\
F L S \_T o n e\end{array}$ & $\begin{array}{l}\text { (5) } \\
F L S_{-} P o s\end{array}$ & $\begin{array}{l}(6) \\
F L S \_P o s\end{array}$ \\
\hline LateRF & $\begin{array}{l}-0.427^{* * * *} \\
(0.026)\end{array}$ & & $\begin{array}{l}-0.015 \\
(0.010)\end{array}$ & & $\begin{array}{l}-0.527^{* * *} \\
(0.031)\end{array}$ & \\
\hline LateRF $\times$ Post & $\begin{array}{l}0.354^{* * *} \\
(0.028)\end{array}$ & $\begin{array}{l}0.357^{\text {*** }} \\
(0.028)\end{array}$ & $\begin{array}{l}0.025^{* *} \\
(0.010)\end{array}$ & $\begin{array}{l}0.030 \text { *** } \\
(0.011)\end{array}$ & $\begin{array}{l}0.490^{* * *} \\
(0.034)\end{array}$ & $\begin{array}{l}0.490^{* * * *} \\
(0.036)\end{array}$ \\
\hline$R O A$ & $\begin{array}{l}-0.373^{* * *} \\
(0.040)\end{array}$ & $\begin{array}{l}-0.245^{\text {**** }} \\
(0.038)\end{array}$ & $\begin{array}{l}-0.047^{* * *} \\
(0.013)\end{array}$ & $\begin{array}{l}0.009 \\
(0.013)\end{array}$ & $\begin{array}{l}-0.496^{* * *} \\
(0.051)\end{array}$ & $\begin{array}{l}-0.275^{* * *} \\
(0.047)\end{array}$ \\
\hline$R E T$ & $\begin{array}{l}-0.036^{* * *} \\
(0.007)\end{array}$ & $\begin{array}{l}-0.023^{\text {**** }} \\
(0.006)\end{array}$ & $\begin{array}{l}-0.003 \\
(0.003)\end{array}$ & $\begin{array}{l}-0.001 \\
(0.003)\end{array}$ & $\begin{array}{l}-0.045^{* * *} \\
(0.009)\end{array}$ & $\begin{array}{l}-0.023^{* * *} \\
(0.008)\end{array}$ \\
\hline Accruals & $\begin{array}{l}0.142^{* *} \\
(0.057)\end{array}$ & $\begin{array}{l}0.040 \\
(0.044)\end{array}$ & $\begin{array}{l}0.026 \\
(0.018)\end{array}$ & $\begin{array}{l}-0.005 \\
(0.015)\end{array}$ & $\begin{array}{l}0.174^{* *} \\
(0.069)\end{array}$ & $\begin{array}{l}0.046 \\
(0.052)\end{array}$ \\
\hline Size & $\begin{array}{l}0.152^{* * * *} \\
(0.006)\end{array}$ & $\begin{array}{l}0.124^{* * * *} \\
(0.015)\end{array}$ & $\begin{array}{l}0.003 \\
(0.002)\end{array}$ & $\begin{array}{l}0.002 \\
(0.005)\end{array}$ & $\begin{array}{l}0.147^{* * * *} \\
(0.007)\end{array}$ & $\begin{array}{l}0.111^{* * * *} \\
(0.019)\end{array}$ \\
\hline$M t o B$ & $\begin{array}{l}-0.002 \\
(0.006)\end{array}$ & $\begin{array}{l}-0.000 \\
(0.006)\end{array}$ & $\begin{array}{l}0.010^{* * * *} \\
(0.002)\end{array}$ & $\begin{array}{l}0.007^{* * * *} \\
(0.002)\end{array}$ & $\begin{array}{l}0.002 \\
(0.007)\end{array}$ & $\begin{array}{l}-0.000 \\
(0.008)\end{array}$ \\
\hline RetVol & $\begin{array}{l}0.954^{* * *} \\
(0.070)\end{array}$ & $\begin{array}{l}0.457^{* * *} \\
(0.062)\end{array}$ & $\begin{array}{l}0.048^{* *} \\
(0.023)\end{array}$ & $\begin{array}{l}0.025 \\
(0.022)\end{array}$ & $\begin{array}{l}1.162^{* * *} \\
(0.088)\end{array}$ & $\begin{array}{l}0.555^{* * *} \\
(0.075)\end{array}$ \\
\hline EarnVol & $\begin{array}{l}0.206^{* * *} \\
(0.043)\end{array}$ & $\begin{array}{l}0.168^{* * *} \\
(0.044)\end{array}$ & $\begin{array}{l}-0.004 \\
(0.009)\end{array}$ & $\begin{array}{l}0.003 \\
(0.014)\end{array}$ & $\begin{array}{l}0.215^{* * *} \\
(0.053)\end{array}$ & $\begin{array}{l}0.247^{* * *} \\
(0.059)\end{array}$ \\
\hline$S P I$ & $\begin{array}{l}0.128 \\
(0.083)\end{array}$ & $\begin{array}{l}0.079 \\
(0.067)\end{array}$ & $\begin{array}{l}0.077^{\text {**** }} \\
(0.023)\end{array}$ & $\begin{array}{l}0.014 \\
(0.022)\end{array}$ & $\begin{array}{l}0.317^{* * * *} \\
(0.102)\end{array}$ & $\begin{array}{l}0.129 \\
(0.085)\end{array}$ \\
\hline FirmAge & $\begin{array}{l}-0.006^{* * *} \\
(0.001)\end{array}$ & $\begin{array}{l}0.079^{* * *} \\
(0.003)\end{array}$ & $\begin{array}{l}0.000 \\
(0.000)\end{array}$ & $\begin{array}{l}-0.004^{* * *} \\
(0.001)\end{array}$ & $\begin{array}{l}-0.003^{* * *} \\
(0.001)\end{array}$ & $\begin{array}{l}0.058^{* * * *} \\
(0.003)\end{array}$ \\
\hline$S E G_{-} B u s$ & $\begin{array}{l}0.047^{* * * *} \\
(0.011)\end{array}$ & $\begin{array}{l}0.029^{*} \\
(0.015)\end{array}$ & $\begin{array}{l}-0.003 \\
(0.003)\end{array}$ & $\begin{array}{l}0.001 \\
(0.006)\end{array}$ & $\begin{array}{l}0.049^{* * * *} \\
(0.012)\end{array}$ & $\begin{array}{l}0.030 \\
(0.019)\end{array}$ \\
\hline$S E G_{-} G e o$ & $\begin{array}{l}-0.038^{* * * *} \\
(0.015)\end{array}$ & $\begin{array}{l}0.040^{* *} \\
(0.020)\end{array}$ & $\begin{array}{l}0.003 \\
(0.005)\end{array}$ & $\begin{array}{l}0.000 \\
(0.007)\end{array}$ & $\begin{array}{l}-0.042^{* *} \\
(0.017)\end{array}$ & $\begin{array}{l}0.052^{* *} \\
(0.025)\end{array}$ \\
\hline$D E$ & $\begin{array}{l}0.080^{* * *} \\
(0.020)\end{array}$ & & $\begin{array}{l}0.012^{*} \\
(0.006)\end{array}$ & & $\begin{array}{l}0.080^{* * *} \\
(0.023)\end{array}$ & \\
\hline $\begin{array}{l}\text { F-value of testing: Lat- } \\
\quad e R F+\text { LateRF } \times \text { Post }=0\end{array}$ & $9.06^{* * *}$ & & 1.77 & & 1.66 & \\
\hline Year FE & Yes & Yes & Yes & Yes & Yes & Yes \\
\hline Industry FE & Yes & No & Yes & No & Yes & No \\
\hline Firm FE & No & Yes & No & Yes & No & Yes \\
\hline \# of Observations & 21,455 & 21,455 & 21,455 & 21,455 & 21,455 & 21,455 \\
\hline Adjusted $\mathrm{R}^{2} \mathrm{~s}$ & 0.298 & 0.284 & 0.043 & 0.019 & 0.222 & 0.179 \\
\hline
\end{tabular}

This table compares the changes in the amount and the tone of FLSs, and the amount of positive FLSs after the $2005 \mathrm{RF}$ mandate for late and early RF disclosers. We estimate the OLS regression: FLS_Amt (FLS_Tone,FLS_Pos $)=\alpha+\beta_{1}$ LateRF $+\beta_{2}$ LateRF $\times$ Post $+\gamma$ Controls. Controls includes ROA, RET, Accruals, Size, MtoB, RetVol, EarnVol, SPI, Firm_Age, SEG_Bus, SEG_Geo and DE. Sample period includes 2000-2004 and 2006-2010. Standard errors clustered at the firm level are reported in parentheses below the coefficients. *, **, and *** indicate significance at the $0.1,0.05$, and 0.01 levels, respectively. Variable definitions are in the Appendix 
that early and late RF disclosers enjoy a similar level of legal protection for FLSs after the 2005 RF mandate.

\subsection{RF disclosure quality and FLSs-2SLS analyses}

In the previous section, we used the $2005 \mathrm{RF}$ mandate as an exogenous shock and a DiD research design to examine whether the mandate increases the amount of positive FLSs among late RF disclosers. Following Petacchi (2015), we now use an alternative research design - a 2SLS model in which the 2005 mandate serves as an instrumental variable - to validate the results of the DiD analyses. We estimate a first-stage regression that identifies exogenous changes in RF disclosure characteristics due to the 2005 mandate and use the predicted RF disclosure characteristics to explain the amount of positive FLSs. Unlike the DiD analyses, this method explicitly shows that the RF mandate results in a strong enough shock to RF disclosure to affect managers' perceived litigation risk. We focus on the length and specificity of RF disclosure because the PSLRA considers cautionary statements as meaningful (to invoke the safe harbor provision) only when they contain comprehensive, specific information (Nelson and Pritchard 2016). The focus on disclosure length and specificity is consistent with court rulings in which judges scrutinize whether RF disclosures are concrete enough and specific enough to constitute meaningful cautionary statements (Rosen and Carey 2016), and with the SEC's recommendation that firms make their cautionary statements "substantive and tailored to the specific projections" to protect FLSs (Hunt 1998). To the extent that managers perceive longer and more specific RF disclosures as offering greater legal protection, we expect the relations between the disclosure length and specificity of risk factors and the amount of firms' positive FLSs to be positive.

We use the following first-stage regression to identify exogenous changes in the length and level of specificity of RF disclosures due to the 2005 mandate:

$$
R F \_ \text {Length or RF_Specificity }=\alpha+\beta_{1} \text { LateRF }+\beta_{2} \text { LateRF } \times \text { Post }+\gamma \text { Controls } .
$$

To measure RF disclosure length ( $R F_{-}$Length), we use the natural log of one plus the number of words in the RF disclosure, scaled by the number of words in the $10-\mathrm{K}$ filing. To measure RF disclosure specificity ( $R F_{-}$Specificity), we follow Hope et al. (2016) and use the proportion of words in the RF disclosure that are identified by the Named Entity Recognition Technique as "specific names" in seven entity categories: (1) names of persons, (2) names of locations, (3) names of organizations, (4) quantitative values in percentages, (5) money values in dollars, (6) times, and (7) dates. We control for the following firm characteristics: ROA, RET, Total_Accruals, SIZE, MtoB, RetVol, EarnVol, SPI, Firm_Age, $S E G_{-} B u s, S E G_{-} G e o, D E$, and industry and year fixed effects.

Columns (1) and (3) of Table 4 report the first-stage regression results for

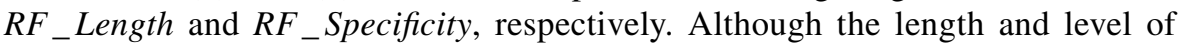
specificity of RF disclosures increase surrounding the time of the RF mandate, the magnitude of these increases is much larger for late RF disclosers. The results of the regression with POST instead of year fixed effects (tabulated in Internet 
Appendix Table IA8) show that late RF disclosers experience increases in RF disclosure length and specificity that are 5.2 times $((0.624+0.148) / 0.148)$ and 3.7 times $((0.345+0.128) / 0.128)$ those of early RF disclosers, respectively. Lat$e R F \times$ Post is significant at the $1 \%$ level in both columns. The estimated coefficients of the control variables are intuitive and consistent with the results in the literature (e.g., Campbell et al. 2014). RF disclosures tend to be longer and more specific when firms are larger, when their performance is poorer, and when they have more volatile earnings and stock returns.

In the second stage, we regress FLS_Pos on the predicted values from the first-stage regressions (Pred_RF_Length and Pred_RF_Specificity). We report the results in Columns (2) and (4) of Table 4. Consistent with our prediction, the coefficients of Pred_RF_Length and Pred_RF_Specificity are positive and significant at the $1 \%$ level, indicating that firms increase their positive FLSs more when their disclosure length and specificity are higher. In particular, one standard deviation increases in Pred_RF_Length and Pred_RF_Specificity are associated with $0.228(0.850 \times 0.268)$ and $0.247(1.470 \times 0.168)$ increases in FLS_Pos, respectively, equal to increases of $27.6 \%$ and $30.2 \%$ in the number of positive words in FLSs (median FLS_Pos is 2.639, meaning that FLSs have a median of 13 positive words), respectively. Therefore, the results of the 2SLS model confirm our DiD analysis findings: late RF disclosers provide a larger amount of positive FLSs after the mandate, compared to early RF disclosers.

\subsection{Changes in the information environment due to the 2005 RF mandate}

To further understand the implication of the mandate's effect on firms' voluntary disclosure, we ask whether the increase in the amount of FLSs provides investors with more useful information or inconsequential or misleading information (H2). We first use the DiD design to test whether late RF disclosers experience an improvement in their information environment compared to early RF disclosers after the mandate:

$$
\text { Spread }=\alpha+\beta_{1} \text { LateRF }+\beta_{2} \text { LateRF } \times \text { Post }+\gamma \text { Controls } 2+\varepsilon,
$$

where, following the literature (e.g., Campbell et al. 2014), we use the bid-ask spread (Spread, the average daily bid-ask spread in percentage) to measure a firm's information environment. ${ }^{33} \mathrm{We}$ control for determinants of the information environment: market-to-book ratio $(M t o B)$, the number of analysts following (Analyst), firm size (Size), profitability (ROA), the number of shareholders (Shareholder), institutional ownership $(I O)$, stock price (Price), return volatility (RetVol), and earnings volatility (EarnVol). To control for time trends and other unobservable time-invariant industry or firm characteristics that might affect the information environment, we include industry and year fixed effects in the model. We provide detailed variable definitions in the Appendix.

\footnotetext{
33 In robustness tests, we measure a firm's information environment using analyst forecast errors and analyst forecast dispersion, and find similar results (tabulated in Internet Appendix Table IA9).
} 
Table 4 Risk factor characteristics and positive forward-looking statements: A two-stage least squares analysis

\begin{tabular}{|c|c|c|c|c|}
\hline & $\begin{array}{l}(1) \\
\text { First Stage } \\
\text { RF_Length }\end{array}$ & $\begin{array}{l}\text { (2) } \\
\text { Second Stage } \\
\text { FLS_Pos }\end{array}$ & $\begin{array}{l}\text { First Stage } \\
\text { RF_Specificity }\end{array}$ & $\begin{array}{l}\text { (4) } \\
\text { Second Stage } \\
\text { FLS_Pos }\end{array}$ \\
\hline LateRF & $\begin{array}{l}-0.618^{* * *} \\
(0.005)\end{array}$ & & $\begin{array}{l}-0.358^{* * *} \\
(0.004)\end{array}$ & \\
\hline LateRF $\times$ Post & $\begin{array}{l}0.615^{* * * *} \\
(0.005)\end{array}$ & & $\begin{array}{l}0.339^{* * * *} \\
(0.005)\end{array}$ & \\
\hline Pred_RF_Length & & $\begin{array}{l}0.850^{* * * *} \\
(0.049)\end{array}$ & & \\
\hline Pred_RF_Specificity & & & & $\begin{array}{l}1.470^{* * * *} \\
(\mathbf{0 . 0 8 5})\end{array}$ \\
\hline$R O A$ & $\begin{array}{l}-0.028^{* * *} \\
(0.010)\end{array}$ & $\begin{array}{l}-0.472^{* * *} \\
(0.051)\end{array}$ & $\begin{array}{l}-0.027^{* * *} \\
(0.008)\end{array}$ & $\begin{array}{l}-0.455^{* * *} \\
(0.051)\end{array}$ \\
\hline RET & $\begin{array}{l}-0.011^{* * *} \\
(0.002)\end{array}$ & $\begin{array}{l}-0.035^{* * *} \\
(0.009)\end{array}$ & $\begin{array}{l}-0.005^{* * *} \\
(0.002)\end{array}$ & $\begin{array}{l}-0.037^{* * *} \\
(0.009)\end{array}$ \\
\hline Accruals & $\begin{array}{l}0.005 \\
(0.015)\end{array}$ & $\begin{array}{l}0.168^{* *} \\
(0.069)\end{array}$ & $\begin{array}{l}-0.007 \\
(0.012)\end{array}$ & $\begin{array}{l}0.184^{* * *} \\
(0.069)\end{array}$ \\
\hline Size & $\begin{array}{l}0.008^{* * *} \\
(0.002)\end{array}$ & $\begin{array}{l}0.139^{* * * *} \\
(0.007)\end{array}$ & $\begin{array}{l}0.008^{* * * *} \\
(0.001)\end{array}$ & $\begin{array}{l}0.135^{\text {**** }} \\
(0.007)\end{array}$ \\
\hline$M t o B$ & $\begin{array}{l}0.002^{*} \\
(0.001)\end{array}$ & $\begin{array}{l}0.000 \\
(0.007)\end{array}$ & $\begin{array}{l}-0.000 \\
(0.001)\end{array}$ & $\begin{array}{l}0.002 \\
(0.007)\end{array}$ \\
\hline RetVol & $\begin{array}{l}0.204^{* * *} \\
(0.020)\end{array}$ & $\begin{array}{l}0.986^{* * *} \\
(0.089)\end{array}$ & $\begin{array}{l}0.156^{* * * *} \\
(0.016)\end{array}$ & $\begin{array}{l}0.932^{* * * *} \\
(0.090)\end{array}$ \\
\hline EarnVol & $\begin{array}{l}0.021^{*} \\
(0.011)\end{array}$ & $\begin{array}{l}0.198^{* * *} \\
(0.053)\end{array}$ & $\begin{array}{l}0.016^{*} \\
(0.009)\end{array}$ & $\begin{array}{l}0.192^{* * * *} \\
(0.053)\end{array}$ \\
\hline$S P I$ & $\begin{array}{l}-0.006 \\
(0.021)\end{array}$ & $\begin{array}{l}0.324^{* * * *} \\
(0.102)\end{array}$ & $\begin{array}{l}0.008 \\
(0.017)\end{array}$ & $\begin{array}{l}0.306^{* * * *} \\
(0.102)\end{array}$ \\
\hline FirmAge & $\begin{array}{l}-0.002^{\text {***** }} \\
(0.000)\end{array}$ & $\begin{array}{l}-0.002^{* *} \\
(0.001)\end{array}$ & $\begin{array}{l}-0.001^{* * * *} \\
(0.000)\end{array}$ & $\begin{array}{l}-0.002^{*} \\
(0.001)\end{array}$ \\
\hline$S E G_{-} B u s$ & $\begin{array}{l}-0.003 \\
(0.002)\end{array}$ & $\begin{array}{l}0.053^{* * *} \\
(0.012)\end{array}$ & $\begin{array}{l}0.003 \\
(0.002)\end{array}$ & $\begin{array}{l}0.045^{* * *} \\
(0.012)\end{array}$ \\
\hline SEG_Geo & $\begin{array}{l}-0.018^{* * * *} \\
(0.004)\end{array}$ & $\begin{array}{l}-0.026 \\
(0.017)\end{array}$ & $\begin{array}{l}-0.007^{* *} \\
(0.003)\end{array}$ & $\begin{array}{l}-0.032^{*} \\
(0.017)\end{array}$ \\
\hline$D E$ & $\begin{array}{l}0.005 \\
(0.004)\end{array}$ & $\begin{array}{l}0.078^{* * *} \\
(0.023)\end{array}$ & $\begin{array}{l}0.001 \\
(0.004)\end{array}$ & $\begin{array}{l}0.078^{* * * *} \\
(0.023)\end{array}$ \\
\hline Year FE & Yes & Yes & Yes & Yes \\
\hline Industry FE & Yes & Yes & Yes & Yes \\
\hline \# of Observations & 21,455 & 21,455 & 21,455 & 21,455 \\
\hline Adjusted $\mathrm{R}^{2} \mathrm{~s}$ & 0.679 & 0.222 & 0.566 & 0.222 \\
\hline
\end{tabular}




\section{Table 4 (continued)}

This table examines the relation between the amount and specificity of risk factor disclosures and the amount of positive FLSs using a two-stage least squares model. In columns (1) and (3), we estimate the first stage OLS regression $R F \_L e n g t h\left(R F \_S p e c i f i c i t y\right)=\alpha+\beta_{1}$ LateRF $+\beta_{2}$ LateRF $\times$ Post $+\gamma$ Controls. Controls includes ROA, RET, Accruals, Size, MtoB, RetVol, EarnVol, SPI, Firm_Age, SEG_Bus, SEG_Geo, and DE. In columns (2) and (4), we estimate the second stage OLS regression: FLS_Pos $=\alpha+\beta$ Pred_RF_Length (Pred_RF_Specificity) $+\gamma$ Controls. Sample period includes 2000-2004 and 2006-2010. Standard errors clustered at the firm level are reported in parentheses below the coefficients. ${ }^{*}, * *$, and $* * *$ indicate significance at the $0.1,0.05$, and 0.01 levels, respectively. Variable definitions are in the Appendix

The results in Table 5, Panel A, show that compared to early RF disclosers, late RF disclosers experience a decrease in bid-ask spreads after the mandate. The estimated coefficients for LateRF $\times$ Post are negative and statistically significant at the $1 \%$ level. Replacing year fixed effects with POST in the regression, we find that the bid-ask spread of late RF disclosers decreases by $41.5 \%$ more than the bid-ask spread of early RF disclosers (i.e., -0.245/-0.591; tabulated in Internet Appendix Table IA10).

Note that the RF mandate can directly affect the information environment of late RF disclosers through RF disclosure itself (Campbell et al. 2014; Filzen 2015; Hope et al. 2016). We therefore perform a path analysis that allows us to separate the RF mandate's direct and indirect effects on the information environment. A path analysis uses a structural equation system to model how a source variable affects an outcome variable directly and indirectly through mediating variables (Wright 1934; Parker and Kyj 2006; Bhattacharya et al. 2012). We use RF disclosure length as the source variable in the path analysis. To quantify the relative importance of the direct and indirect paths, we follow Bhattacharya et al. (2012) and do not include control variables. ${ }^{34}$

Panel B of Table 5 shows the path analysis results. The Pearson correlation between $R F \_$Length and Spread, which measures the total effect of RF length on the bid-ask spread, is -0.19 . This result is consistent with the assertion that the overall effect of RF disclosure on firms' information environment is positive. The direct path coefficient, $p\left[R F \_\right.$Length,Spread $]$, is -0.15 (significant at the 0.01 level). The path coefficient for the indirect path - the product of $p\left[R F_{-}\right.$Length,FLS_Pos $]$and $p\left[F L S \_P o s\right.$, Spread $]$ (both significant at the 0.01 level $)$ - is $-0.04(0.296 \times-0.135)$. That is, additional RF disclosure improves firms' information environment both directly, and indirectly through the increase in positive FLSs. Following Bhattacharya et al. (2012), we estimate the relative importance of the direct and indirect paths as the ratio of each path coefficient to the total correlation. The direct path contributes $78.9 \%$ to the total effect of RF_Length on Spread. More importantly, the indirect path contributes $21.1 \%$ of the total effect. These results suggest that a considerable portion of the RF mandate's effect on the information environment of late RF disclosers is through additional positive FLSs. This finding dispels the concern that firms use the RF disclosure's safe harbor protection as a license to lie, and points to an unintended benefit of the RF mandate for investors.

\footnotetext{
${ }^{34}$ We conduct several sensitivity tests for the path analysis. We include the control variables in the path analysis and use alternative source variables_RF_Specificity, Pred_RF_Length, and Pred_RF_Specificity (the latter two being the predicted RF length and predicted RF specificity from the first-stage regressions in the 2SLS analyses). The results, tabulated in Internet Appendix Table IA11, are similar.
} 
Table 5 Changes in information environment after the 2005 RF mandate

\begin{tabular}{|c|c|c|}
\hline \multicolumn{3}{|c|}{ Panel A. Changes in information environment after the 2005 RF mandate - a DiD analysis } \\
\hline & \multicolumn{2}{|l|}{ Spread } \\
\hline \multirow[t]{2}{*}{ LateRF } & $0.252^{* * *}$ & \\
\hline & $(0.040)$ & \\
\hline \multirow[t]{2}{*}{ LateRF $\times$ Post } & $-0.147^{* * * *}$ & \\
\hline & $(\mathbf{0 . 0 4 3 )}$ & \\
\hline \multirow[t]{2}{*}{$M t o B$} & $-0.081^{* * *}$ & \\
\hline & $(0.012)$ & \\
\hline \multirow[t]{2}{*}{ Analyst } & $-0.188^{* * *}$ & \\
\hline & $(0.011)$ & \\
\hline \multirow[t]{2}{*}{ Size } & $-0.153^{* * *}$ & \\
\hline & $(0.014)$ & \\
\hline \multirow[t]{2}{*}{$R O A$} & $0.214^{* * *}$ & \\
\hline & $(0.071)$ & \\
\hline \multirow[t]{2}{*}{ Shareholder } & $0.046^{* * *}$ & \\
\hline & $(0.012)$ & \\
\hline \multirow[t]{2}{*}{ IO } & $-0.127^{* * * *}$ & \\
\hline & $(0.047)$ & \\
\hline \multirow[t]{2}{*}{ Price } & $-0.629^{* * *}$ & \\
\hline & $(0.023)$ & \\
\hline \multirow[t]{2}{*}{ RetVol } & $-0.341^{* *}$ & \\
\hline & $(0.159)$ & \\
\hline \multirow[t]{2}{*}{ EarnVol } & $-0.182^{*}$ & \\
\hline & $(0.099)$ & \\
\hline Year FE & Yes & \\
\hline Industry FE & Yes & \\
\hline \# of Observations & 26,601 & \\
\hline Adjusted $\mathrm{R}^{2} \mathrm{~s}$ & 0.572 & \\
\hline \multicolumn{3}{|c|}{$\begin{array}{l}\text { Panel } B \text {. The effect of risk factor length on information environment following the } 2005 \text { RF mandate - a } \\
\text { path analysis }\end{array}$} \\
\hline & Coefficients & $t$-statistic \\
\hline$r\left[R F \_\right.$Length,Spread $]$ & $-0.190 * * *$ & -26.15 \\
\hline \multicolumn{3}{|l|}{ Direct path } \\
\hline$p\left[R F \_\right.$Length,Spread $]$ & $-0.150^{* * *}$ & -19.90 \\
\hline percentage & $78.94 \%$ & \\
\hline \multicolumn{3}{|l|}{ Indirect Path } \\
\hline$p\left[R F \_L e n g t h, F L S \_P o s\right]$ & $0.296 * * *$ & 41.88 \\
\hline$p\left[F L S_{-}\right.$Pos, Spread $]$ & $-0.135^{* * *}$ & -17.86 \\
\hline Total indirect path & -0.040 & \\
\hline percentage & $21.06 \%$ & \\
\hline
\end{tabular}


Table 5 (continued)

Panel A compares the changes in information environment, measured with bid-ask spread, after the 2005 mandate for late and early RF disclosers. We estimate the OLS regression: Spread $=\alpha+\beta_{1}$ Lat$e R F+\beta_{2}$ LateRF $\times$ Post $+\gamma$ Controls2. Controls 2 include MtoB, Analyst, Size, ROA, Shareholder, IO, Price, RetVol, and EarnVol. Sample period includes 2000-2004 and 2006-2010. Standard errors clustered at the firm level are reported in parentheses below the coefficients. *, **, and *** indicate significance at the 0.1, 0.05, and 0.01 levels, respectively. Variable definitions are in the Appendix

Panel B reports the direct and indirect effects (through the amount of positive FLS disclosure) of risk factor length on information environment, measured with bid-ask spread. $r$ indicates Pearson correlation coefficient, and $p$ indicates the path coefficients. $* * *$, and $* * *$ indicate significance at the $0.1,0.05$, and 0.01 levels, respectively. Variable definitions are in the Appendix

\subsection{Cross-sectional tests of the changes in FLSs due to the $2005 \mathrm{RF}$ mandate}

If the 2005 RF mandate influences firms' voluntary forward-looking disclosures through managers' perception of litigation risk, we expect the effect to be stronger when managers perceive a higher level of legal benefit from meaningful cautionary statements (H3). We measure legal benefit three ways.

First, securities class action lawsuits are more likely to target firms whose FLSs turn out to be overly optimistic (Rogers et al. 2011). We therefore identify firms that are more susceptible to large unexpected negative events-namely, firms that have more volatile earnings (Graham et al. 2005; Dichev and Tang 2009), that are in competitive industries (Lev 1983; Zang 2012), or that invest in highly uncertain projects (Wedig 1990; Chan et al. 2001; Shi 2003). To measure earnings volatility, we use the standard deviation of earnings over the previous five years (Earn$V o l$ ). To measure industry competition, we use the Herfindahl index (Competition, the sum of the squared market shares of the ten largest companies in the industry, multiplied by negative one; a larger value denotes a more competitive industry). To measure investment in uncertain projects, we use R\&D expenditure intensity $(R \& D)$.

Second, we explore the variation in the legal protection of risk factors that arises from the judicial system. Huang et al. (2019) show that when judges have more liberal ideology, they are more likely to make pro-plaintiff decisions in securities class action lawsuits. We expect firms that reside in a more proplaintiff circuit to demonstrate a higher need for meaningful cautionary language in their legal defense and to thus experience stronger effects from the RF mandate. To measure how pro-plaintiff the court is, we use the ideology of the judges of the circuit court that has jurisdiction over the state of the firm's headquarters (Judge_Ideology, the probability of a randomly selected threejudge panel from the circuit being dominated by those appointed by Democratic presidents). ${ }^{35}$

Third, when managers are more familiar with the role of meaningful cautionary statements in lawsuits, they are likely to perceive a higher level of legal benefit for

\footnotetext{
${ }^{35}$ A circuit court assigns a panel of three judges, who are randomly selected from the circuit, to each case.
} 
their RF disclosures. To measure managers' familiarity with meaningful cautionary statements and the safe harbor provision, we consider whether their firm has been sued in securities class action lawsuits in the past (PastLawsuit, an indicator variable that equals one if the firm has been sued during the pre-mandate period, and zero otherwise).

For our cross-sectional tests, we estimate Eq. (1) separately for the subsamples of firms that have above versus below sample median values of EarnVol, Competition, $R \& D$, and Judge_Ideology, and for the subsamples of firms whose PastLawsuit equals one versus zero. We compare the coefficients of LateRF $\times$ Post across these samples. H3 predicts that the coefficients of LateRF $\times$ Post are larger in the subsamples of firms that have above sample median values of EarnVol, Competition, $R \& D$, and Judge_Ideology, and whose PastLawsuit equals one.

We find that the estimated coefficients of LateRF $\times$ Post are positive and significant in all of the subsamples. However, the coefficients are significantly larger when firms' FLSs are more susceptible to potential litigation (in Columns (2), (4), and (6) of Table 6, for above sample median values of EarnVol, Competition, and $R \& D$, respectively); when meaningful cautionary statements have a greater impact on potential lawsuit outcomes (in Column (8), for an above sample median value of Judge_Ideology); and when managers are more familiar with the role of meaningful cautionary statements in lawsuits (in Column (10), where PastLawsuit is equal to one). All of these are consistent with $\mathrm{H} 3$. These results support those of our earlier analyses and indicate that the RF mandate affects FLSs by changing managers' perception of legal protection.

\subsection{Robustness tests}

\subsubsection{Matched sample test}

In Section 4.1, we verify that the parallel trend assumption for the DiD analyses is satisfied for our main sample. Nonetheless, in a sensitivity test, we use the propensity score matching technique to mitigate functional form misspecification (Shipman et al. 2017). We match each late RF discloser with an early RF discloser based on their firm characteristics in 2004 (the year before the RF mandate) or the latest prior year with available data if the firm has missing data in 2004. Following Shipman et al. (2017), we include the control variables in Table 3 in the propensity score estimation model, with a caliper of 0.01 as matching criteria, and match without replacement. In the matched sample, six of the 12 firm characteristics of the late and early RF disclosers are not statistically different, the exceptions being ROA, Accruals, EarnVol, RetVol, SPI, and FirmAge (tabulated in Panel A of Internet Appendix Table IA6). Using the matched sample, we obtain similar results to those of the main tests (tabulated in Panel B of Internet Appendix Table IA6), confirming that our main findings are not driven by differences in economic fundamentals between the treatment and control groups. 


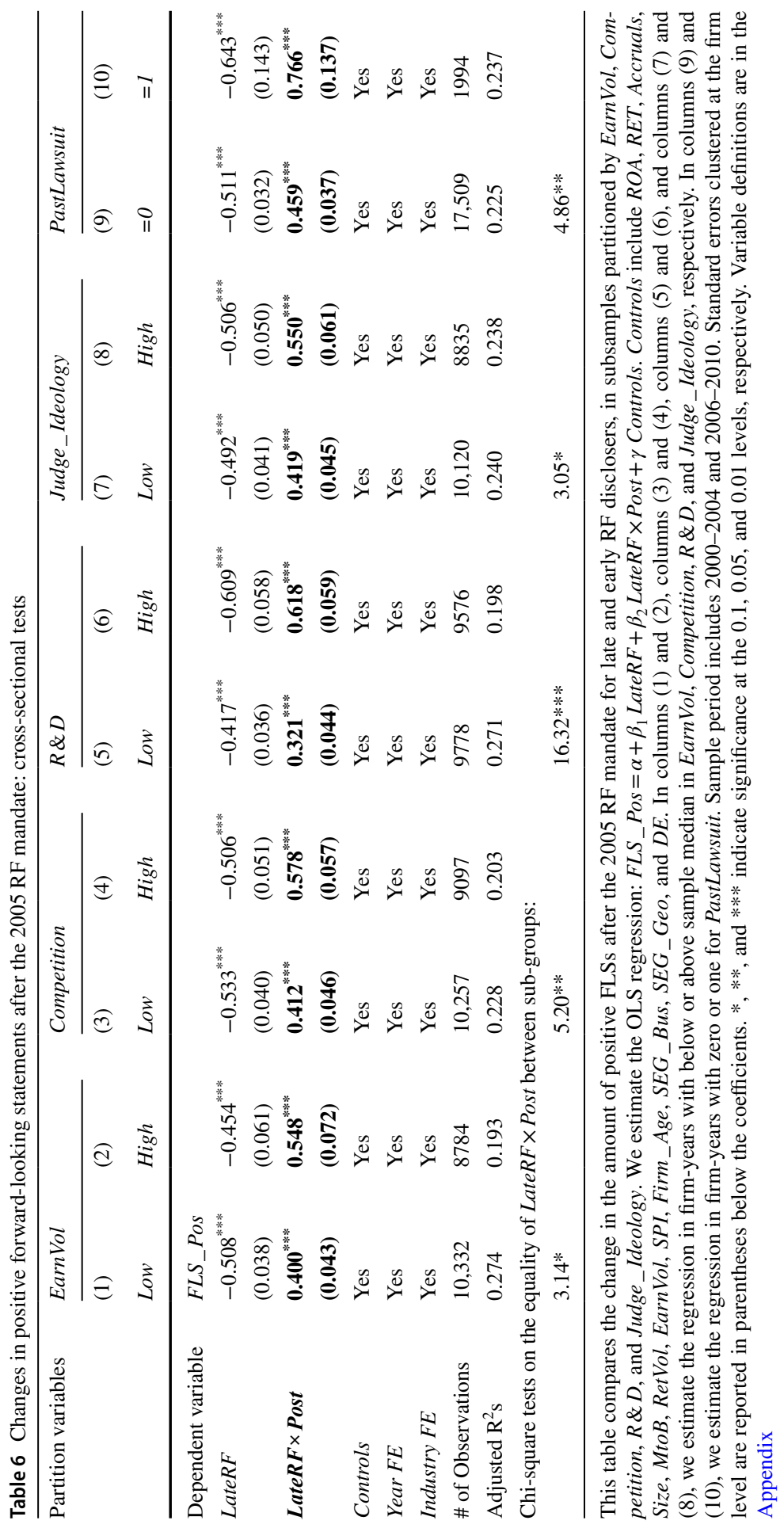




\subsubsection{Alternative sample period}

In our main tests, we use the 2000-2004 and 2006-2010 periods as the pre- and post-mandate windows, respectively. As a sensitivity test, we vary the length of the pre- and post-mandate windows to one-, two-, and four-year windows around 2005 (i.e., 2004 and 2006; 2003-2004 and 2006-2007; and 2001-2004 and 2006-2009, respectively) and re-estimate Eq. (1). ${ }^{36}$ The results (reported in Columns (1) to (3) of Internet Appendix Table IA1) are similar to those of our main analyses. In particular, all of the coefficients for LateRF $\times$ Post are positive and significant at the $1 \%$ level.

We exclude the 2005 fiscal year from the main analyses' sample period because the mandate took effect during 2005. In the 2005 fiscal year, firms with a year-end from December 2005 to May 2006 are affected, whereas firms with a year-end from June to November 2005 are not. In this sensitivity test, we include firm-year observations from the 2005 fiscal year and classify firms with a 2005 fiscal year-end from June to November 2005 as pre-mandate observations (Post equals zero) and the others as post-mandate observations (Post equals one). The results (tabulated in Column (4) of Internet Appendix Table IA1) are consistent with those of the main analyses.

In another sensitivity test, we exclude the first year that the late RF disclosers are under the mandate (i.e., firm-year observations with a 2005 fiscal year-end between December 2005 and November 2006), to ensure that our results are not driven by the firms' managers providing forward-looking information to mitigate the market reaction to negative news (Gennotte and Trueman 1996; Segal and Segal 2016) and to resolve the increased uncertainty from the disclosed risk factors (Kravet and Muslu 2013). The results remain similar (tabulated in Column (5) of Internet Appendix Table IA1).

The SEC first proposed the RF mandate on November 3, 2004. If some firms started to provide RF disclosures as soon as the proposal was announced rather than wait until the mandate officially took effect in 2005, this might introduce measurement errors in our classification of late and early RF disclosers. In a robustness test, we use January 1, 2000, to October 31, 2004, as the pre-mandate window to classify early and late RF disclosers. We find a change in classification from early to late RF disclosers for only 66 firms - that is, these firms began to voluntarily disclose risk factors between November 1, 2004, and November 30, 2005. We estimate our main regressions using this alternative classification and find similar results (reported in Column (6) of Internet Appendix Table IA1).

\subsubsection{Other disclosure regulations}

The 2005 Securities Offering Reform, which includes the RF mandate, allows firms to more freely disclose information before equity offerings (SEC 2005; Shroff et al.

\footnotetext{
36 Excluding 2000 from our sample ensures that our results are not affected by the pre-regulation Fair Disclosure period, when managers could selectively disclose forward-looking information to analysts without making public disclosures. Similarly, excluding 2008 and 2009 from our sample mitigates the concern that our results are driven by the financial crisis period.
} 
2013; Clinton et al. 2014). To ensure that our results are not driven by differences in equity issuance between early and late RF disclosers, we exclude all firm-years in which the firm issued equity, according to the SDC database, and re-estimate our main test in Table 3. We find similar results (tabulated in Internet Appendix Table IA12).

As discussed in Section 2.2, firms were required to disclose risk factors in their IPO prospectus before the 2005 mandate. Before 2005, newly listed firms could rely on the risk factors in their prospectus to protect their FLSs. As a result, they might feel less need to disclose risk factors in their 10-Ks. However, this concern is unlikely to drive our results, because the late RF disclosers in our sample are older than the early RF disclosers (the median age of the two groups of firms in 2004 is 18 and 10 years, respectively). Nonetheless, we exclude all firms that became publicly traded after 2000 (185 firms) and find similar results (tabulated in Internet Appendix Table IA13).

\subsubsection{A placebo test}

We conduct a placebo test by examining the changes in mandatory disclosure after the RF mandate for late and early RF disclosers. Our prediction and findings are such that the 2005 RF mandate decreases managers' perception of litigation risk, which increases their tendency to issue voluntary FLSs. This mechanism should not apply to firms' mandatory disclosures. Following $\mathrm{He}$ and Plumlee (2020), we use firms' mandatory 8-K filings (i.e., 8-Ks without Items 2.02, 7.01 , or 8.01 ) to measure the likelihood of issuing mandatory disclosure and its amount. We re-estimate Eq. (1) using mandatory disclosure as the dependent variable. Consistent with our expectations, late RF disclosers do not change their mandatory disclosure practices compared with early RF disclosers following the RF mandate (reported in Internet Appendix Table IA14).

\section{Conclusion}

We examine the effect of the SEC's 2005 RF mandate on firms' voluntary disclosure of FLSs. We show that the mandate has an unintended benefit-it encourages firms to provide more FLSs, which in turn improves their information environment. These findings contribute to the understanding of the costs and benefits of the RF mandate, which is a controversial regulation. Despite the mandate's intention to provide the market with more information about firm risks, firms use a substantial amount of boilerplate language in RF disclosures to exploit the potential legal benefit.

Studies that examine the information content of RF disclosures find mixed evidence. We take a different angle and examine an unintended consequence of the disclosure mandate-its legal protection for firms' voluntary disclosures (i.e., the issuance of FLSs). We find that managers perceive lower litigation risk in providing FLSs because they treat the mandated RF disclosures as meaningful cautionary language under the PSLRA. When we conduct a DiD analysis to compare the firms that 
did and did not provide RF disclosures before the 2005 mandate was enacted, we find that firms that did not provide RF disclosures before 2005 became more willing to provide FLSs, particularly positive ones, after the mandate. We confirm this result with an alternative research design of a 2 SLS model that uses the RF mandate as an instrumental variable and tests whether exogenous changes in RF disclosure due to the RF mandate explain firms' issuance of FLSs. Moreover, our evidence indicates that the 2005 RF mandate is beneficial to investors, as evidenced by an improvement in the information environment of late RF disclosers. Using a path analysis, we show that a considerable portion of the mandate's positive effect on firms' information environment is through an increase in the level of positive FLSs. We also find that the mandate's effect is greater for firms whose managers perceive a higher level of legal benefit from the provision of meaningful cautionary statements.

Overall, we extend the understanding of the costs and benefits of the RF mandate by documenting an unintended benefit of the regulation: the mandate reduces managers' perceived litigation risk and prompts firms to provide more forward-looking information, a type of voluntary disclosure that investors welcome and demand, which in turn improves the information environment. These insights are relevant to both regulators and market participants and highlight the importance of considering the unintended costs and benefits of disclosure regulations. We also contribute to the literature on litigation risk by documenting that the provision of meaningful cautionary language affects managers' perceived safe harbor protection and in turn increases their willingness to disclose qualitative FLSs.

\section{Appendix: Variable definitions}

\begin{tabular}{|c|c|}
\hline Variables & Definitions \\
\hline LateRF & $\begin{array}{l}\text { An indicator variable that equals one if the firm is a late RF discloser, and zero } \\
\text { otherwise. Late RF disclosers are firms that do not have risk factor disclosure } \\
\text { in their 10-Ks between January } 1,2000 \text { and December } 1,2005 \text {. }\end{array}$ \\
\hline Post & $\begin{array}{l}\text { An indicator variable that equals one if the fiscal year is after 2005, and zero } \\
\text { otherwise. }\end{array}$ \\
\hline$F L S \_A m t$ & 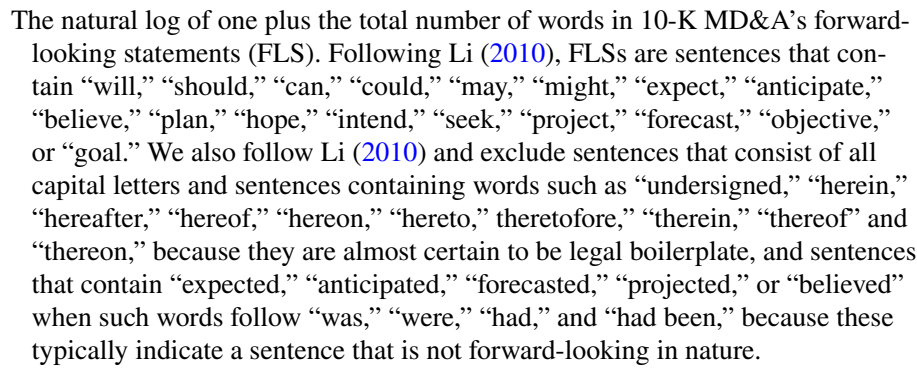 \\
\hline FLS_Tone & $\begin{array}{l}\text { The natural log of one plus the number of positive words scaled by that of nega- } \\
\text { tive words, both from 10-K MD\&A's FLSs. Positive and negative word lists are } \\
\text { constructed by Loughran and McDonald (2011). }\end{array}$ \\
\hline$F L S_{-} P o s$ & The natural log of one plus the number of positive words in MD\&A's FLSs. \\
\hline
\end{tabular}




\begin{tabular}{|c|c|}
\hline Variables & Definitions \\
\hline$R O A$ & $\begin{array}{l}\text { The net income (NI) in year } t \text { scaled by the book value of total assets }(A T) \text { at the } \\
\text { end of year } t \text {. }\end{array}$ \\
\hline$R E T$ & The cumulative raw monthly returns (RET) during year $t$. \\
\hline Accruals & $\begin{array}{l}\text { Net income minus operating cash flows in year } t \text {, scaled by book value of total } \\
\text { assets at the end of year } t((N I-O A N C F) / A T) \text {. }\end{array}$ \\
\hline Size & The natural log of total assets ( $A T$, in millions) at the end of year $t$. \\
\hline MtoB & $\begin{array}{l}\text { The market value of equity }\left(C S H O \times P R C C_{-} F\right) \text { plus the book value of total } \\
\text { liabilities }(L T) \text {, scaled by the book value of total assets }(A T) \text {, all measured at } \\
\text { the end of year } t \text {. }\end{array}$ \\
\hline RetVol & The standard deviation of monthly raw returns $(R E T)$ in year $t$. \\
\hline EarnVol & The standard deviation of $R O A$ over years $t-4$ to $t$. \\
\hline$S P I$ & $\begin{array}{l}\text { The amount of special items (SPI) scaled by total assets }(A T) \text {, both measured at } \\
\text { the end of year } t \text {. }\end{array}$ \\
\hline FirmAge & The number of years since the firm first appeared in CRSP. \\
\hline$S E G_{-} B u s$ & The natural log of one plus the number of business segments. \\
\hline$S E G \_G e o$ & The natural log of one plus the number of geographic segments. \\
\hline$D E$ & $\begin{array}{l}\text { An indicator variable that equals one if the firm is incorporated in Delaware, and } \\
\text { zero otherwise. }\end{array}$ \\
\hline Competition & $\begin{array}{l}\text { Negative one times the sum of squared market share of the ten largest companies } \\
\text { in terms of sales in the 2-digit SIC code industry that the firm-year belongs } \\
\text { to. Market share is the average of the ratio of firm sales }(S A L E) \text { to the industry } \\
\text { sales during the pre-mandate period (i.e., years 2000-2004). }\end{array}$ \\
\hline$R \& D$ & $\begin{array}{l}\text { The average of annual R\&D expenditure }(X R D) \text { scaled by total assets }(A T) \text { during } \\
\text { the pre-mandate period (i.e., years } 2000-2004) \text {. Missing R\&Ds are set to zero. }\end{array}$ \\
\hline Judge_Ideology & $\begin{array}{l}\text { The probability that a three-judge panel randomly selected from a circuit court } \\
\text { has at least two judges appointed by Democratic presidents, that is, }[C(x, 3)+ \\
C(x, 2) \times C(y-x, 1)] / C(y, 3) \text {, where } y \text { is the total number of judges in the circuit } \\
\text { court and } x \text { is the number of judges in the circuit court who were appointed by } \\
\text { Democratic presidents. } C(a, b) \text { is the number of combinations of selecting } b \\
\text { objects from } a \text { distinct objects. We assign each firm-year observation to a cir- } \\
\text { cuit court-month based on the firm's headquarters at the beginning of the year. } \\
\text { We obtain historical headquarters information from firms' 10-K filings and } \\
\text { circuit court judges' appointing presidents from the Federal Judicial Center's } \\
\text { website. }\end{array}$ \\
\hline PastLawsuit & $\begin{array}{l}\text { An indicator variable that equals one if the firm had a securities class action law- } \\
\text { suit during the pre-mandate period (i.e., years 2000-2004), and zero otherwise. }\end{array}$ \\
\hline Spread & $\begin{array}{l}\text { The average daily bid-ask spread during a year. Daily bid-ask spread is the abso- } \\
\text { lute value of closing ask price minus closing bid price scaled by the average of } \\
\text { closing bid and ask prices. We require at least } 200 \text { trading days during a year. }\end{array}$ \\
\hline Price & The natural logarithm of stock price $\left(P R C C_{-} F\right)$ at the end of year $t$. \\
\hline Analyst & $\begin{array}{l}\text { The natural logarithm of one plus the number of analysts who have issued earn- } \\
\text { ings forecasts for the firm during year } t \text {. }\end{array}$ \\
\hline Shareholder & $\begin{array}{l}\text { The natural logarithm of one plus the number of shareholders (CSHR) at the end } \\
\text { of year } t \text {. }\end{array}$ \\
\hline$I O$ & $\begin{array}{l}\text { The average institutional ownership (number of shares held by institutional } \\
\text { investors, as recorded in Thomson Reuters institutional (13f) holding database, } \\
\text { scaled by common shares outstanding) of the four quarters during year } t \text {. }\end{array}$ \\
\hline$R F \_$Length & $\begin{array}{l}\text { The natural log of one plus the number of words in the risk factor disclosure } \\
\text { scaled by the natural log of one plus the number of words in the } 10-\mathrm{K} \text {. }\end{array}$ \\
\hline
\end{tabular}




\begin{tabular}{|c|c|}
\hline Variables & Definitions \\
\hline$\overline{R F \_S p e c i f i c i t y}$ & $\begin{array}{l}\text { The natural log of one plus the number of specific words in the risk factor disclo- } \\
\text { sure divided by the natural log of one plus the total number of words in the risk } \\
\text { factor disclosure. Following Hope et al. (2016), we define words as specific } \\
\text { words if they are identified by the Stanford Named Entity Recognition program } \\
\text { to belong to one of the seven entity categories, including: (1) names of persons, } \\
\text { (2) names of locations, (3) names of organizations, (4) quantitative values in } \\
\text { percentages, (5) money values in dollars, (6) times, and (7) dates. }\end{array}$ \\
\hline $\begin{array}{l}\text { Pred_RF_Length } \\
\text { Pred_RF_Specificity }\end{array}$ & $\begin{array}{l}\text { The fitted values from estimating the following models: } R F_{-} \text {Length }(\text { RF_Speci- } \\
\text { ficity })=\alpha+\beta_{1} \text { LateRF }+\beta_{2} \text { LateRF } \times \text { Post }+\gamma \text { Controls. Controls includes ROA, } \\
\text { RET, Accruals, Size, MtoB, RetVol, EarnVol, SPI, Firm_Age, SEG_Bus, } \\
\text { SEG_Geo, DE, year fixed effects, and industry fixed effects. }\end{array}$ \\
\hline
\end{tabular}

Supplementary Information The online version contains supplementary material available at https://doi. org/10.1007/s11142-021-09590-z.

Acknowledgements We appreciate and acknowledge comments from Scott Bauguess, Utpal Bhattacharya, Allison Koester, Wayne Guay, Bin Ke, Reining Petacchi, Adam Pritchard, Xiaoli Tian, Chris Williams (discussant), Joanna Wu, and workshop participants at CUHK, CUHK Shenzhen, Georgetown University, HKU, HKUST, NUS, Peking University, the SEC's Division of Economic and Risk Analysis, Shanghai University of Finance and Economics, Tsinghua University, University of Melbourne, University of Minnesota, University of Sydney and MIT Asia Conference in Accounting. Any remaining errors and omissions are ours. Allen Huang and Amy Zang would like to express thanks for financial support provided by HKUST. Jianghua Shen would like to express thanks for financial support provided by HKUST, Xiamen University, and National Natural Science Foundation of China (NSFC-71790602).

Open Access This article is licensed under a Creative Commons Attribution 4.0 International License, which permits use, sharing, adaptation, distribution and reproduction in any medium or format, as long as you give appropriate credit to the original author(s) and the source, provide a link to the Creative Commons licence, and indicate if changes were made. The images or other third party material in this article are included in the article's Creative Commons licence, unless indicated otherwise in a credit line to the material. If material is not included in the article's Creative Commons licence and your intended use is not permitted by statutory regulation or exceeds the permitted use, you will need to obtain permission directly from the copyright holder. To view a copy of this licence, visit http://creativecommons.org/licen ses/by/4.0/.

\section{References}

Aboody, D., and R. Kasznik. 2000. CEO stock option awards and the timing of corporate voluntary disclosures. Journal of Accounting and Economics 29 (1): 73-100.

Asay, H.S., and J. Hales. 2018. Disclaiming the future: Investigating the impact of cautionary disclaimers on investor judgments before and after experiencing economic loss. The Accounting Review 93 (4): 81-99.

Austin, A.K., and S.V. Bernard. 2016. Risk factors disclosure and the private securities litigation reform act. Working paper.

Baker, L.A., M.A. Perino, and C. Silver. 2015. Is the price right? An empirical study of fee-setting in securities class actions. Columbia Law Review 115 (6): 1371-1452.

Bao, D., Y. Kim, G.M. Mian, and L. Su. 2019. Do managers disclose or withhold bad news? Evidence from short interest. The Accounting Review 94 (3): 1-26.

Beatty, A., L. Cheng, and H. Zhang. 2015. Sometimes less is more: evidence from financial constraints risk factor disclosures. Working paper. 
Beatty, A., L. Cheng, and H. Zhang. 2019. Are risk factor disclosures still relevant? Evidence from market reactions to risk factor disclosures before and after the financial crisis. Contemporary Accounting Research 36 (2): 805-838.

Bhattacharya, N., F. Ecker, P.M. Olsson, and P.M. Schipper. 2012. Direct and mediated associations among earnings quality, information asymmetry, and the cost of equity. The Accounting Review 87 (2): 449-482.

Brown, S.V., X. Tian, and J.W. Tucker. 2018. The spillover effect of SEC comment letters on qualitative corporate disclosure: Evidence from the risk factor disclosure. Contemporary Accounting Research 35 (2): 622-656.

Brusch, M.D., and M.C. McGough. 2016. National investor relations institute on business and financial disclosure required by regulation S-K, August 4th. Available at: https://www.sec.gov/ comments/s7-06-16/s70616-350.pdf.

Calomiris, C., and M. Jaremski. 2019. Stealing deposits: Deposit insurance, risk-taking, and the removal of market discipline in early $20^{\text {th }}$-century banks. Journal of Finance 74 (2): 711-754.

Campbell, J.L., H. Chen, D.S. Dhaliwal, H. Lu, and L.B. Steele. 2014. The information content of mandatory risk factor disclosures in corporate filings. Review of Accounting Studies 19 (1): $396-455$.

Cao, Z., and G.S. Narayanamoorthy. 2010. The effect of litigation risk on management earnings forecasts. Contemporary Accounting Research 28 (1): 125-173.

Cazier, R.A., K.J. Merkeley, and J.S. Treu. 2020. When are firms sued for qualitative disclosures? Implications of the safe harbor for forward-looking statements. The Accounting Review 95 (1): 31-55.

CFA Institute. 2013. Financial reporting disclosures: Investor perceptions on transparency, trust and volume. CFA Institute, Business institute roundtable for corporate ethics. Available at: https://www. cfainstitute.org/en/advocacy/policy-positions/financial-reporting-disclosures-investor-perspectiveson-transparency-trust-and-volume.

CFA Institute. 2014. Forward-looking information: A necessary consideration in the SEC's review on disclosure effectiveness. CFA Institute, Business Institute Roundtable for Corporate Ethics. Available at: https://www.cfainstitute.org/en/advocacy/policy-positions/forward-looking-information-anecessary-consideration-in-the-secs-review-on-disclosure-effectiveness.

Chan, L.K.C., J. Lakonishok, and T. Sougiannis. 2001. The stock market valuation of research and development expenditures. Journal of Finance 56 (6): 2431-2456.

Clinton, S.B., J.T. White, and T. Woidtke. 2014. Differences in the information environment prior to seasoned equity offerings under relaxed disclosure regulation. Journal of Accounting and Economics 58 (1): 59-78.

Coffee, J.C., Jr. 1996. The future of the private securities litigation reform act: Or, why the fat lady has not yet sung. The Business Lawyer 51 (4): 975-1007.

Cole, C.J., and C.L. Jones. 2005. Management discussion and analysis: A review and implications for future research. Journal of Accounting Literature 24: 135-174.

Core, J.E. 2001. A review of the empirical disclosure literature: Discussion. Journal of Accounting and Economics 31 (1-3): 441-456.

Cutler, J., A.K. Davis, and K. Peterson. 2019. Disclosure and the outcome of securities litigation. Review of Accounting Studies 24 (1): 230-263.

De Figueiredo, M.J. 2005. Strategic plaintiffs and ideological judges in telecommunications litigation. Journal of Law, Economics and Organization 21 (2): 501-523.

DeLong, G., and A. Saunders. 2011. Did the introduction of fixed-rate federal deposit insurance increase long-term bank risk-taking? Journal of Financial Stability 7 (1): 19-25.

Dichev, I.D., and V.W. Tang. 2009. Earnings volatility and earnings predictability. Journal of Accounting and Economics 47 (1-2): 160-181.

Dyer, T., M. Lang, and L. Stice-Lawrence. 2017. The evolution of 10-K textual disclosure: Evidence from latent Dirichlet allocation. Journal of Accounting and Economics 64 (2-3): 221-245.

Ellis, J.A., C.E. Fee, and S.E. Thomas. 2012. Proprietary costs and the disclosure of information about customers. Journal of Accounting Research 50 (3): 685-727.

Ericson, B.A., and S. Kinser. 2015. Court of appeals warns against complacency in the PSLRA's safe harbor. Available at: https://www.dandodiary.com/2015/08/articles/securities-litigation/guest-postcourt-of-appeals-warns-against-complacency-in-the-pslras-safe-harbor/.

Ernst \& Young. 2018. SEC annual reports - Form 10-K.

Filzen, J.J. 2015. The information content of risk factor disclosures in quarterly reports. Accounting Horizons 29 (4): 887-916. 
Fitzpatrick, B.T. 2010. An empirical study of class action settlements and their fee awards. Journal of Empirical Legal Studies 7 (4): 811-846.

Francis, J., D. Philbrick, and K. Schipper. 1994. Shareholder litigation and corporate disclosures. Journal of Accounting Research 32 (2): 137-164.

Franke, B., A. Huang, and R. Li. 2021. Securities law precedent, litigation risk, and misreporting. Working paper.

Garmong, S. 2007. Management discussion and analysis in accountants' handbook, volume one: Financial accounting and general topics. New Jersey: Wiley.

Gelfond, S., J. Wechsler, and H. Cohen. 2018. Top 10 practice tips: Risk factor disclosures. Available at https://www.lexisnexis.com/lexis-practice-advisor/the-journal/b/lpa/posts/top-10-practice-tips-riskfactor-disclosures.

Gennotte, G., and B. Trueman. 1996. The strategic timing of corporate disclosures. Review of Financial Studies 9 (2): 665-690.

Graham, J.R., C.R. Harvey, and S. Rajgopal. 2005. The economic implications of corporate financial reporting. Journal of Accounting and Economics 40 (1-3): 3-73.

Hazen, T.L. 2011. Federal securities law. Third Edition, Published by Federal Judicial Center.

He, J., and M. Plumlee. 2020. Measuring disclosure using 8K filings. Review of Accounting Studies 25 (3): 903-962.

Healy, P.M., and K.G. Palepu. 2001. Information asymmetry, corporate disclosure, and the capital markets: A review of the empirical disclosure literature. Journal of Accounting and Economics 31 (1-3): 405-440.

Hedlund, J. 2000. Risk business: Safety regulations, risk compensation, and individual behavior. Injury Prevention 6 (2): 82-90.

Heinle, M.S., K.C. Smith, and R.E. Verrecchia. 2018. Risk factor disclosure and asset prices. The Accounting Review 93 (2): 191-208.

Hope, O.-K., D. Hu, and H. Lu. 2016. The benefits of specific risk-factor disclosures. Review of Accounting Studies 21 (4): 1005-1045.

Horwich, A. 2010. Cleaning the murky safe harbor for forward-looking statements: An inquiry into whether actual knowledge of falsity precludes the meaningful cautionary statement defense. The Journal of Corporation Law 35: 519-559.

Houston, J.F., C. Lin, S. Liu, and L. Wei. 2019. Litigation risk and voluntary disclosure: Evidence from legal changes. The Accounting Review 94 (5): 247-272.

Huang, X., S.H. Teoh, and Y. Zhang. 2013. Tone management. The Accounting Review 89 (3): 1083-1113.

Huang, A., A.Y. Zang, and R. Zheng. 2014. Evidence on the information content of text in analyst reports. The Accounting Review 89 (6): 2151-2180.

Huang, A., K.W. Hui, and R.Z. Li. 2019. Federal judge ideology: A new measure of ex-ante litigation risk. Journal of Accounting Research 57 (2): 431-489.

Hunt, I.C. Jr. 1998. Litigation reform, safe harbors, and other matters of interest. Orange County Public Company Forum. Available at https://www.sec.gov/news/speech/speecharchive/1998/spch204.txt.

IRRC Institute. 2016. The corporate risk factor disclosure landscape. Available at: https://www.weinberg. udel.edu/IIRCiResearchDocuments/2016/01/FINAL-EY-Risk-Disclosure-Study.pdf.

Israelsen, R.D., and S.E. Yonker. 2017. Key human capital. Journal of Financial and Quantitative Analysis 52 (1): 175-214.

Johnson, S. 2010. SEC pushes companies for more risk information. CFO Magazine, August 2.

Johnson, M.F., R. Kasznik, and K.K. Nelson. 2001. The impact of securities litigation reform on the disclosure of forward-looking information by high technology firms. Journal of Accounting Research 39 (2): 297-327.

Kim, I., and D.J. Skinner. 2012. Measuring securities litigation risk. Journal of Accounting and Economics 53 (1-2): 290-310.

Kravet, T., and V. Muslu. 2013. Textual risk disclosures and investors' risk perceptions. Review of Accounting Studies 18 (4): 1088-1122.

Lang, M.H., and R.J. Lundholm. 2000. Voluntary disclosure and equity offerings: Reducing information asymmetry or hyping the stock. Contemporary Accounting Research 17 (4): 623-662.

Leuz, C., and P.D. Wysocki. 2016. The economics of disclosure and financial reporting regulation: Evidence and suggestions for future research. Journal of Accounting Research 54 (2): 525-622.

Lev, B. 1983. Some economic determinants of time-series properties of earnings. Journal of Accounting and Economics 5 (1): 31-48. 
Levitt, A. 1995. Letter to committee on banking, housing, and urban affairs. Washington, DC: U.S. Senate.

Levitt, A. 1996. Final thoughts on litigation reform. $23^{\text {rd }}$ Annual securities regulation institute. San Diego, California. Available at: https://digital.sandiego.edu/sdlr/vol33/iss3/3/.

Li, F. 2010. The information content of forward-looking statements in corporate filings: A Naïve Bayesian machine learning approach. Journal of Accounting Research 48 (5): 1049-1102.

Li, X., and H.I. Yang. 2016. Mandatory financial reporting and voluntary disclosure: The effect of mandatory IFRS adoption on management forecasts. The Accounting Review 91 (3): 933-953.

Loughran, T., and B. Mcdonald. 2011. When is a liability not a liability? Textual analysis, dictionaries, and 10-Ks. The Journal of Finance 66 (1): 35-65.

Lowry, M. 2009. Discussion of 'shareholder litigation and changes in disclosure behavior.' Journal of Accounting and Economics 47 (1-2): 157-159.

Marinovic, I., and F. Varas. 2016. No news is good news: Voluntary disclosure in the face of litigation. The Rand Journal of Economics 47 (4): 822-856.

McCann, D. 2018. Study pans disclaimers on forward-looking statements. CFO.com.

McClane, J. 2019. Boilerplate and the impact of disclosure in securities dealmaking. Vanderbilt Law Review 72 (1): 191-295.

Muslu, V., S. Radhakrishnan, K.R. Subramanyam, and D. Lim. 2015. Forward-looking MD\&A disclosures and the information environment. Management Science 61 (5): 931-948.

Naughton, J.P., T.O. Rusticus, C. Wang, and I. Yeung. 2019. Private litigation costs and voluntary disclosure: Evidence from the Morrison rulings. The Accounting Review 94 (3): 303-327.

Nelson, K.K., and A.C. Pritchard. 2007. Litigation risk and voluntary disclosure: The use of meaningful cautionary language. Working paper. Available at: https://papers.ssrn.com/sol3/papers.cfm?abstr act_id=998590.

Nelson, K.K., and A.C. Pritchard. 2016. Carrot or stick? The shift from voluntary to mandatory disclosure of risk factors. Journal of Empirical Legal Studies 13 (2): 266-297.

Olazabal, A. 2011. False forward-looking statements and the PSLRA's safe harbor. Indiana Law Journal 86 (2): 595-643.

Parker, R., and L. Kyj. 2006. Vertical information sharing in the budgeting process. Accounting, Organizations and Society 31 (1): 27-45.

Peltzman, S. 1975. The effects of automobile safety regulation. Journal of Political Economy 83 (4): $677-725$.

Petacchi, R. 2015. Information asymmetry and capital structure: Evidence from regulation FD. Journal of Accounting and Economics 59 (2-3): 143-162.

Phillips, R.O., A. Fyhri, and F. Sagberg. 2011. Risk compensation and bicycle helmets. Risk Analysis 31 (8): 1187-1195.

Pritchard, A.C., and H.A. Sale. 2005. What counts as fraud? An empirical study of motion to dismiss under the private securities litigation reform act. Journal of Empirical Legal Studies 2 (1): 125-149.

Robbins, R.B., and P.L. Rothenberg. 2005. Writing effective risk factor disclosure in offering documents and exchange act reports. Insights, The Corporate \& Securities Law Advisor 19 (5): 9-16.

Rogers, J.L., and A. Van Buskirk. 2009. Shareholder litigation and changes in disclosure behavior. Journal of Accounting and Economics 47 (1-2): 136-156.

Rogers, J.L., A. Van Buskirk, and S.L.C. Zechman. 2011. Disclosure tone and shareholder litigation. The Accounting Review 86 (6): 2155-2183.

Rosen, R.A., and J.S. Carey. 2016. The safe harbor for forward-looking statements after twenty years. Insights, The Corporate \& Securities Law Advisor 30 (5): 8-31.

Securities and Exchange Commission (SEC). 1989. Management's discussion and analysis of financial condition and results of operations; Certain investment company disclosures. Release No. 33-6835. Available at https://www.sec.gov/rules/interp/33-6835.htm.

Securities and Exchange Commission (SEC). 1997a. Final Rules 33-7386. Available at https://www.sec. gov/rules/final/33-7386.txt.

Securities and Exchange Commission (SEC). 1997b. Report to the president and the congress on the first year of practice under the private securities litigation reform act of 1995. Available at https://www. sec.gov/news/studies/lreform.txt.

Securities and Exchange Commission (SEC). 1998. A plain English handbook (How to create clear SEC disclosure documents). Available at https://www.sec.gov/pdf/handbook.pdf. 
Securities and Exchange Commission (SEC). 2003. Commission guidance regarding management's discussion and analysis of financial condition and results of operations. Release No. 33-8350. Available at https://www.sec.gov/rules/interp/33-8350.htm.

Securities and Exchange Commission (SEC). 2004. Securities offering reform. Release No. $33-8501$. Available at https://www.sec.gov/rules/proposed/33-8501.htm.

Securities and Exchange Commission (SEC). 2005. The securities offering reform adopting release. Release No. 33-8591. Available at https://www.sec.gov/rules/final/33-8591.pdf.

Securities and Exchange Commission (SEC). 2013. Report on review of disclosure requirements in regulation S-K. Available at https://www.sec.gov/news/speech/spch101513mjw.

Securities and Exchange Commission (SEC). 2016. Concept release: Business and financial required by regulation S-K. Release No. 33-10064. Available at https://www.sec.gov/rules/concept/2016/3310064.pdf.

Securities and Exchange Commission (SEC). 2020. Management's discussion and analysis, selected financial data, and supplementary financial information. Release No. 33-10750. Available at https://www.sec.gov/rules/proposed/2020/33-10750.pdf.

Segal, B., and D. Segal. 2016. Are managers strategic in reporting non-earnings news? Evidence on timing and news bundling. Review of Accounting Studies 21 (4): 1203-1244.

Senate Report. 1995. The private securities litigation reform act of 1995. Available at: https://www.govin fo.gov/content/pkg/CRPT-104srpt98/html/CRPT-104srpt98.htm.

Shearman and Sterling. 2014. Disclosure effectiveness, comment letter to SEC. Available at https://www. sec.gov/comments/disclosure-effectiveness/disclosureeffectiveness-25.pdf.

Shi, C. 2003. On the trade-off between the future benefits and riskiness of R\&D: A bondholders' perspective. Journal of Accounting and Economics 35 (2): 227-254.

Shipman, J.E., Q.T. Swanquist, and R.L. Whited. 2017. Propensity score matching in accounting research. The Accounting Review 92 (1): 213-244.

Shroff, N., A.X. Sun, H.D. White, and W. Zhang. 2013. Voluntary disclosure and information asymmetry: Evidence from the 2005 securities offering reform. Journal of Accounting Research 51 (5): 1299-1345.

Skinner, D.J. 1997. Earnings disclosures and stockholder lawsuits. Journal of Accounting and Economics 23 (3): 249-282.

U.S. Congress. 1995. Conference Report. Available at: https://www.govinfo.gov/content/pkg/CREC1995-12-06/html/CREC-1995-12-06-pt1-PgH14039-2.htm.

Verrecchia, R.E. 1983. Discretionary disclosure. Journal of Accounting and Economics 5 (1): 179-194.

Wachtell, Lipton, Rosen and Katz Re. 2016. File No. S7-06-16, Release Nos. 33-10064, 34-77599. "Business and financial disclosure required by regulation S-K.". Available at https://www.sec.gov/ comments/s7-06-16/s70616-9.pdf.

Waymire, G. 1985. Earnings volatility and voluntary management forecast disclosure. Journal of Accounting Research 23 (1): 268-295.

Wedig, G.J. 1990. How risky is R and D? A financial approach. Review of Economics and Statistics 72 (2): 296-302.

White, M.J. 2013. The path forward on disclosure. Leadership Conference 2013 in National Harbor, MD. Available at: https://www.sec.gov/news/speech/spch101513mjw.

Wright, S. 1934. The method of path coefficients. Annals of Mathematical Statistics 5 (3): 161-215.

Zang, A.Y. 2012. Evidence on the trade-off between real activities manipulation and accrual-based earnings management. The Accounting Review 87 (2): 675-703.

Publisher's note Springer Nature remains neutral with regard to jurisdictional claims in published maps and institutional affiliations. 